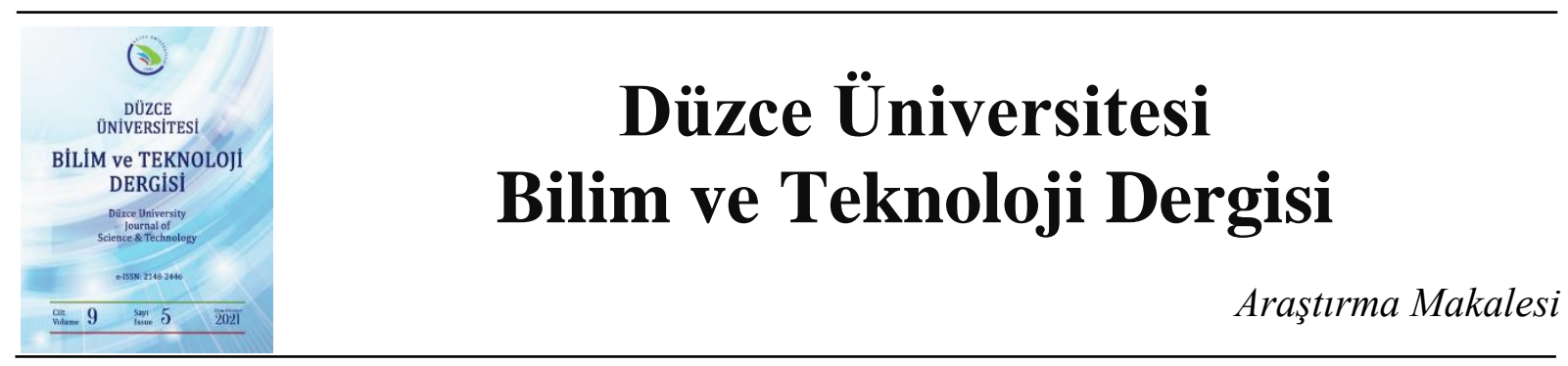

\title{
Düzce Kentinde Dikey Bahçe Uygulanabilirliğinin Araştırılması
}

\author{
(D) Özge DEDEİ DÜNDAR ${ }^{\mathrm{a}, *}$, (D) Zeki DEMIR ${ }^{\mathrm{b}}$ \\ ${ }^{a}$ Peyzaj Mimarlı̆̆ Bölümü, Fen Bilimleri Enstitüsü, Düzce Üniversitesi, Düzce, TÜRKIYYE \\ ${ }^{b}$ Peyzaj Mimarlığı Bölümü, Orman Fakültesi, Düzce Üniversitesi, Düzce, TÜRKIYYE \\ * Sorumlu yazarin e-posta adresi: ozgededei.sd@gmail.com
}

DOI: $10.29130 /$ dubited.941832

\begin{abstract}
$\underline{\mathrm{O} z}$
Dikey bahçeler, şehirlerde git gide azalan yeşil alan gereksinimini kısmen gidermek ve tek düze betonlaşma arasında alternatif yeşili yaşatmak için ortaya çıkmış en iyi buluşlardandır. "Yaşayan Duvar" adıyla da anılan dikey bahçeler, yapıların dış yüzeylerinde ve topraksız ortamda canlı bitki yetiştirilmesi esasına dayalıdır.Dış mekanda uygulanan dikey bahçeler kentlerde; yeşil alan miktarını, hava ve yaşam kalitesini artırma, biyolojik çeşitlilik sağlayarak ekolojik bilinci yaygınlaştırma etkileriyle beraber 1si-enerji bütçesi, toz partiküllerini tutarak karbondioksit salınımını azaltma gibi önemli konularda da iyileştirmeler yapmaktadır. Dikey bahçeler uygulandığ 1 alandaki etkilerinin yanı sıra psikolojik olarak kişilerde olumlu hislere ve düşüncelere de sebep olmaktadır.Bu çalışma kapsamında Düzce'nin kimliğini yansıtabilecek kilit bölgeler (Çoban Dalçık, Asar Deresi, Düzce Şehirler Arası Otobüs Terminali) seçilerek alanlara uygun iki boyutlu ve üç boyutlu dikey bahçe tasarımları (Efteni Gölü, Akçakoca İlçesi, Konuralp Antik Kent Kalıntıları, Düzce İli’nde Yapılan Spor Dalları) yapılarak; yapay-doğal, estetik-estetik değil, yorucu-dinlendirici, uyumsuz-uyumlu, karışık-anlaşılır, sıradan-modern karşılaştırılmalı sıfatlarla tanımlanarak anket çalışmasıyla kullanıcılara sunulmuştur.
\end{abstract}

Anahtar Kelimeler: Dikey bahçe, Dikey bahçe tasartmlarl, Dikey bahçe sistemleri, Düzce.

\section{Investigation of Vertical Gardening Applicabilityin City Center of Düzce}

\begin{abstract}
Vertical gardens are one of the best inventions that have emerged in order to partially meet the decreasing need for green space in cities and to provide alternative greenery among the uniform concreting. Vertical gardens, also known as the "Living Wall", are based on the principle of growing live plants on the outer surfaces of the buildings and in a soilless environment.Vertical gardens applied outdoors in cities; In addition to its effects on increasing the amount of green space, air and life quality, and extending ecological awareness by providing biodiversity, it also makes improvements in important issues such as heat-energy budget, reducing carbon dioxide emissions by keeping dust particles. In addition to the effects of vertical gardens in the area where it is applied, it also causes positive feelings and thoughts in people psychologically. Within the scope of this study, two-dimensional and threedimensional vertical garden designs suitable for the areas (Efteni Lake, Akçakoca District, Konuralp Ancient City Ruins, Düzce Province) were selected by selecting the key regions that can reflect the identity of Düzce (Çoban Dalçık, Asar Creek, Düzce Intercity Bus Terminal) by doing Sports Branches; artificial-natural, aesthetic-not aesthetic, tiring-relaxing, incompatible-harmonious, mixed-understandable, ordinary-modern comparative adjectives and presented to users through a survey study.
\end{abstract}

Keywords: Vertical garden, Vertical garden designs, Vertical garden systems, Düzce. 


\section{GİRIS}

Dünya daha kalabalık bir hal almaya başladığında göçebelikten yerleşik hayata geçişler artmış ve kentlerdeki yoğunluk fazlalaşmıştır. Bu fazlalık kentsel katliamları da beraberinde getirmiş ve kentsel hayat yeşilden uzak, ağaçlarla süslü arazilerin yerini devasa yapıların aldığı yerler olmuştur [1].20. yüzyılın ortalarında hızlanan çarpık kentleşme, 21. yüzyıl kentleşmesinde yeşil alanların yetersiz kalmasına neden olmuştur. Kentlerde yaşayan insanların beden ve ruh sağlıkları, kentleşme sürecinde olumsuz etkilenmiştir[2].

Yeşil hayat için ayakta kalmanın giderek güçleştiği yeni düzende, çevrecilerin doğayı koruma serzenişlerine 20. yüzyılın belki de en önemli çevreci mimarı Patrick Blanch cevap vermiştir. Blanch'e göre ne inşa etmek zorunda olunan yapılardan ne de yeşilden vazgeçilmek zorunda kalınacaktır. Bulunan çevreci çözümle tüm duvarlar yemyeşil bahçelere dönüştürülebilirdi [1].

Dikey bahçelerin ortaya çıkmasını bu kadar ilginç kılan şey, bahçelerin başlangıçta bir zamanlar kentin ve daha sonra bahçenin bulunduğu kırsal ve kentsel ortamlar arasında arabulucu olarak kullanılmasıydı. $\mathrm{Bu}$ kentsel bahçe biçimi, genellikle şehirlerdeki binaları süslemek için bir sanat formu olarak tasarlanmıştır ve şehirleri daha keyifli, daha sağlıklı ve nihayetinde daha yeşil yerler haline getirmenin bir yolu olarak kabul edilmiştir [3].

"Dikey bahçe" veya "Dikey peyzaj" adı verilen uygulama, hızlı kentleşmenin yaşandığı metropol kentlerde tercih edilmeye ve başta Avrupa olmak üzere tüm dünyada hızla yayılmaya başladı; duvarları gri görünümünden kurtarıp, sanatsal tablo görüntüsüne bürünmüştür. Kentlerde yeşile duyulan özleme cevap, estetik açıdan arzu edilen görüntüye yeni bir soluk, ekolojik olarak kente fayda sağlayan, insan psikolojisi üzerinde olumlu etki ve yatayda yer kaplamayarak bahçe formuna farklı bir boyut kazandıran dikey bahçeler sağlık - estetik yönünden olumlu etkileriyle ön plana çıkmışlardır. Kent tasarımına yeni bir soluk getiren dikey bahçeler, daha ekolojik daha sıcak ortamlar oluşturmanın yanı sıra bitkilerin tarımsal öğe dışında farklı boyutlarda yorumlanabileceğini göstermiş̦tir [4].

Grafiti, çoğunlukla kamusal bir alanda yer alan bir duvar ya da yüzeye çizilmiş, kazınmış veya püskürtülmüş yazı ve çizimlerdir [5]. İlk çağlardan beri bir durumu resmetme, tanımlama ya da dikkat çekme yöntemlerinden birisidir [6].Bugün bilinen anlamıyla grafiti, 1960'ların sonlarında Amerika Birleşik Devletleri'nin hip hop kültürüyle birlikte doğmuştur. Modern şehirlerde otobüslerin içlerine sivri bir aletle kazınan yazılardan sokak duvarlarına sprey boyayla çizilen resimlere kadar pek çok uygulama grafitinin kapsamına girmektedir. Kimi çevrelerce bir sanat dalı olarak kabul edilirken, bir başka bakış açısı da, grafitiyi vandalizm olarak değerlendirmekte ve suçla ilişkilendirmektedir. II. Dünya Savaşı'nda propaganda aracı olarak kullanılan grafiti, günümüzdeki anlamıla 1960'lı yıllarda Amerika'da, özellikle New York'ta politik eylemciler ve sokak çeteleri, seslerini duyurmak ve kendi çetelerinin sınırlarını belirlemek için benimsenen bir yöntem olarak ortaya çıkmıştır. 1970'li yıllarda ortaya çıkan rap ve hip-hop kültürü, grafitinin dünyada yaygınlaşmasını sağlamıştır[5]. Grafiti altkültürünün merkezindeki rekabet ve "Stil Savaşları" balon şeklinde olan harflerden, "stamp" (damga) olarak bilinen üç boyutlu grafitilere ve karmaşık "wildstyle" (vahşi stile) doğru bir evrimleşmeyi sağlamıştır [7]. 1980'lerde "Style Wars" ve "Wild Style" adlı iki belgesel grafiti ve hip hop kültürünün geniş kitlelere yayılmasında rol oynamıştır[8]. Avrupa'nın ve Güney Amerika'nın politik sorunlar yaşayan bölgelerinde yoğun olarak görülmeye başladı. Doksanlı yıllarda grafiti kendine özgü bir giyim, yaşam tarzı ve literatür oluşturdu. ThieryNoir adlı bir sokak sanatçısının Berlin Duvarı'nın yıkılışına eşlik eden grafitileri uluslararası bir ün kazanarak grafiti üzerinden özgürlük isteminin sanatsal bir ifadesi olmuştur[6]. Grafitinin kaligrafik biçimi, ikibinli yılların sunduğu kültürel ve teknik olanaklar ile yepyeni bir boyut kazanmıştır. Günümüzde sokak sanatçısı, ismini değil vermek istediği mesaj1 yaymayı amaçlamakta ve çok daha çeşitli materyalleri kullanmaktadır [6]. Peyzajda kullanılan "Konuşan Duvarlar" da grafitinin günümüzde şekillenmiş bir hali olup kötü görüntüye sahip duvarların renklenmesinde kullanılır. 
Bu çalışmanın amacı; Düzce Kenti'nin önemli geçiş noktaları için kentin kimliğini yansıtacak tasarımlar yapılarak kullanıcıların görsel algılarının hangi niteliklere göre değişim gösterdiğini belirleyerek, dikey bahçe için en uygun materyal seçimi yapmaktır. Kentte seçilen noktalardaki duvarların olumsuz görüntülerini iyileştirmek amacıyla bu alanlarda oluşturulacak dikey bahçe için tasarlanan 3 boyutlu modeller üzerinden en uygun seçenek belirlenmiştir. Kentin kimliği ile uyumlu, kenti sembolize eden tasarımların hazırlanmasında kullanılan her bir tasarım için en uygun materyalin araştırılması yapılmış ve her bir alan için tasarımın yapıldı̆̆ 1 duvarlara uygun kentin kimliğini ortaya çıkaracak malzeme belirlenmiştir.

\section{MATERYAL VE YÖNTEM}

\section{A. MATERYAL}

Çalışma alanı olarak Batı Karadeniz Bölgesi'ne ait olan Düzce İli seçilmiştir. Düzce konumu itibariyle doğu-batı yönünde uzanan D-100 karayolu ile TEM otobanı üzerinde yer alır ve bu yollar il merkezinden geçer. Bu konumu ile Avrupa-Asya arasında transit yol üzerinde bulunan Düzce, D-100 karayolu ile il merkezinden ayrılarak Akçakoca ilçesi üzerinden Zonguldak İli’ne bağlanır ve yol kavşağı şehri olma özelliğine sahip olur [9].

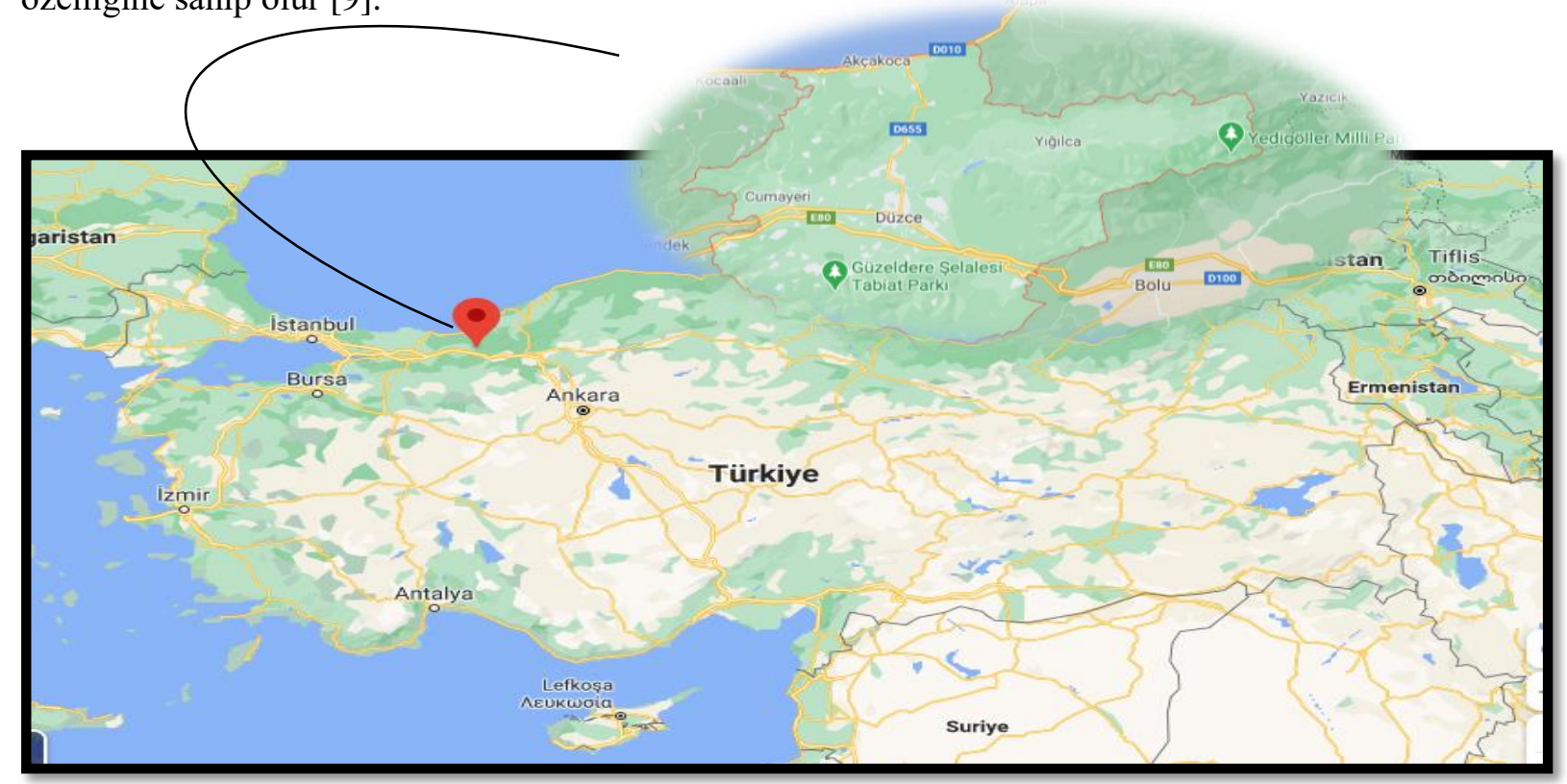

Şekil 1. Çallşma Alanı İl Konumu.

Öncelikle Düzce İli kent merkezinde görsel olarak hoş gözükmeyen duvarların kötü görüntüsünü ortadan kaldırmak için dikey bahçe uygulaması yapabilecek alanlar tespit edilmiştir. Bu amaçla yapılan çalışmanın materyalini, belirlenen alanlarda ne tür uygulama yapılacağına karar vermek için yazılı kaynaklardan alternatifler araştırılmıştır. Bu alanları belirlemek için imar planlarından, yerinde gözlem, fotoğraflama ve daha önceden çekilmiş görsellerden yararlanılmıştır. Belirlenen alanlar için tasarlanacak dikey bahçe figürlerini oluşturmak için Düzce'ye özgü tarihi ve doğal alanlar araştırılmıştır. Bu amaçla yerel yönetimlerle bilgi alışverişinde bulunulmuş, alanlara ait 3 boyutlu modeller ve modeller hakkında kullanıcı düşünceleri ortaya koymak için anket uygulaması yapılmıştır. Anketlerin değerlendirilmesinde SPSS programı kullanılmıştır. 


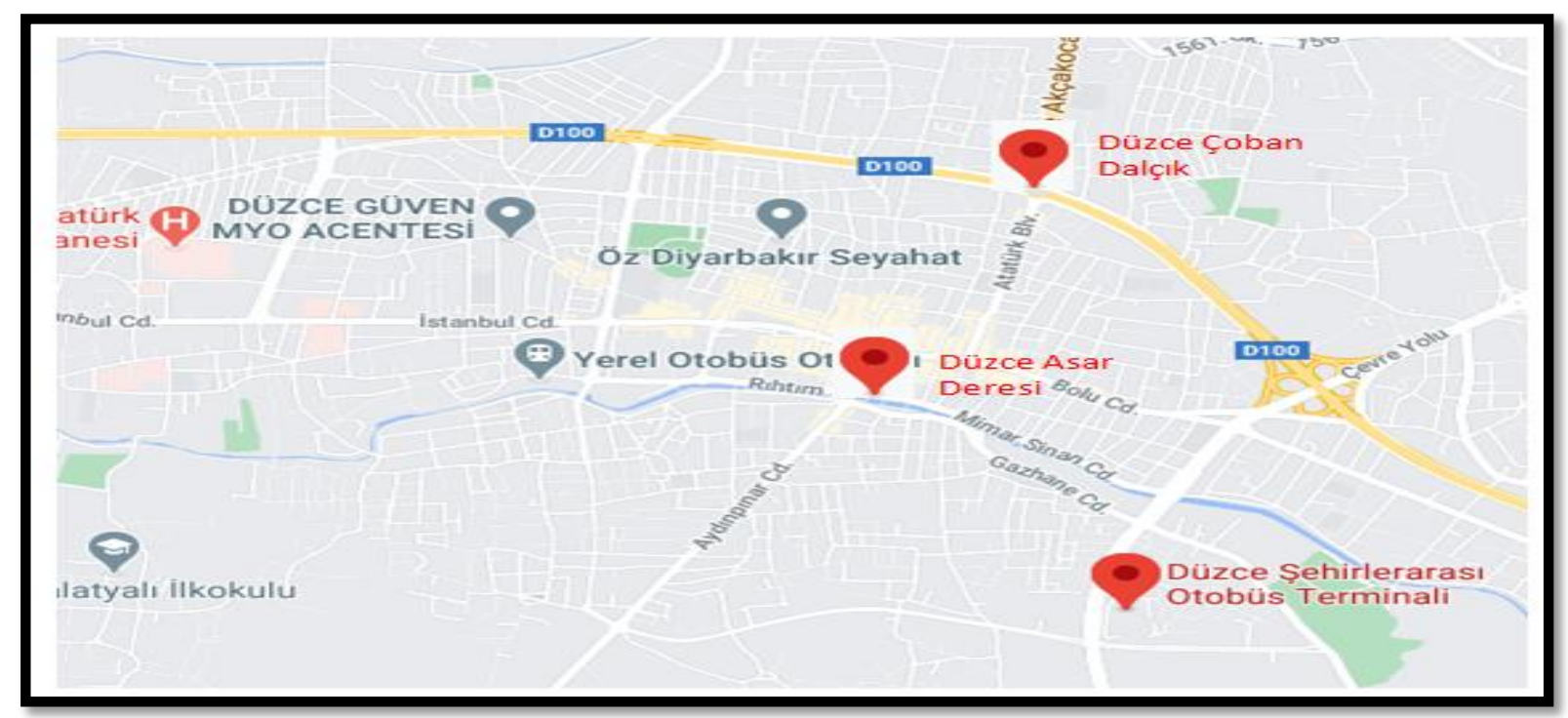

Şekil 2. Dikey Bahçe Tasarım Uygulamalarının Önerileceği Alanlar.

Literatür araştırmaları sonucunda dikey bahçelerin uygulanacağı alanlar arasında amaç kente kimlik kazandırmak, kentin tanıtımında görsellik ve estetik açısından katkı sağlamak ise kentin kilit noktalarını oluşturacak bölgelerin seçilme önceliğidir. Bu veriler göz önünde bulundurularak seçilen alanlarda Düzce'nin tarihiyle, doğasıyla, sosyal uğraşılarıyla bütünleşmiş figürler ile tasarımlar yapılmış, bu tasarımlarda; kentin transit yol üzerindeki Çoban Dalçık duvarları, kent insanı kadar turistlerin geçiş noktası Şehirler Arası Otobüs Terminali duvarları ve kent merkezinden geçen Asar Deresi duvarlarında gösterilmiştir.

\section{A. 1. Çoban Dalçık}
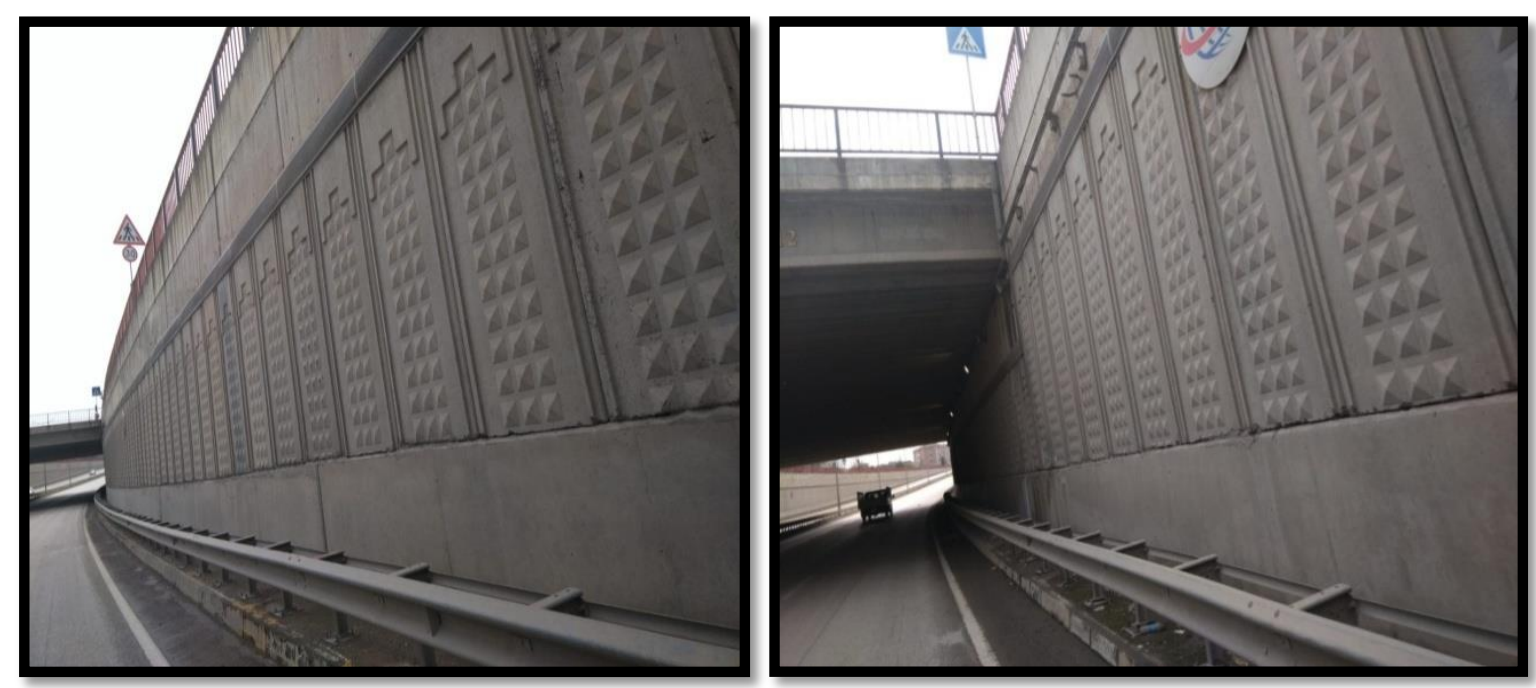

Şekil 3. Çoban Dalçık Orijinal,2019.

Düzce'nin D-100 karayolu Çoban mevkiinde bulunan 2010 yılında trafiğe açılan dalçık, şehrin doğu ve batı yol güzergahını kesintisiz hale getirmiştir. Yolun her iki bölümünde trafik üç şerit üzerinden akıyor ve orta refüj ile yeşil alan gereksinimini karşılamaya çalışmaktadır[9].İstanbul ve Ankara arasında bulunan Düzce, bu yol aksında yapılandırdığı dalçıkla transit geçişlere uygun bir istikamet oluşturmuştur. $\mathrm{Bu}$ alana dikey bahçe uygulama fikrinin sebebi ise, geçişlerde yetersiz kalan yeşilin refüjle karşılanamamasının yanı sıra Dalçık duvarlarındaki kötü görüntüye görsellik katmak ve bu görselliği şehre kimlik kazandıran sembolleşmiş değerlerin yeşille sunularak akılda kalıcılığının sağlanma isteğinin düşünülmesidir. 


\section{A. 2. Düzce Şehirler Arası Otobüs Terminali}

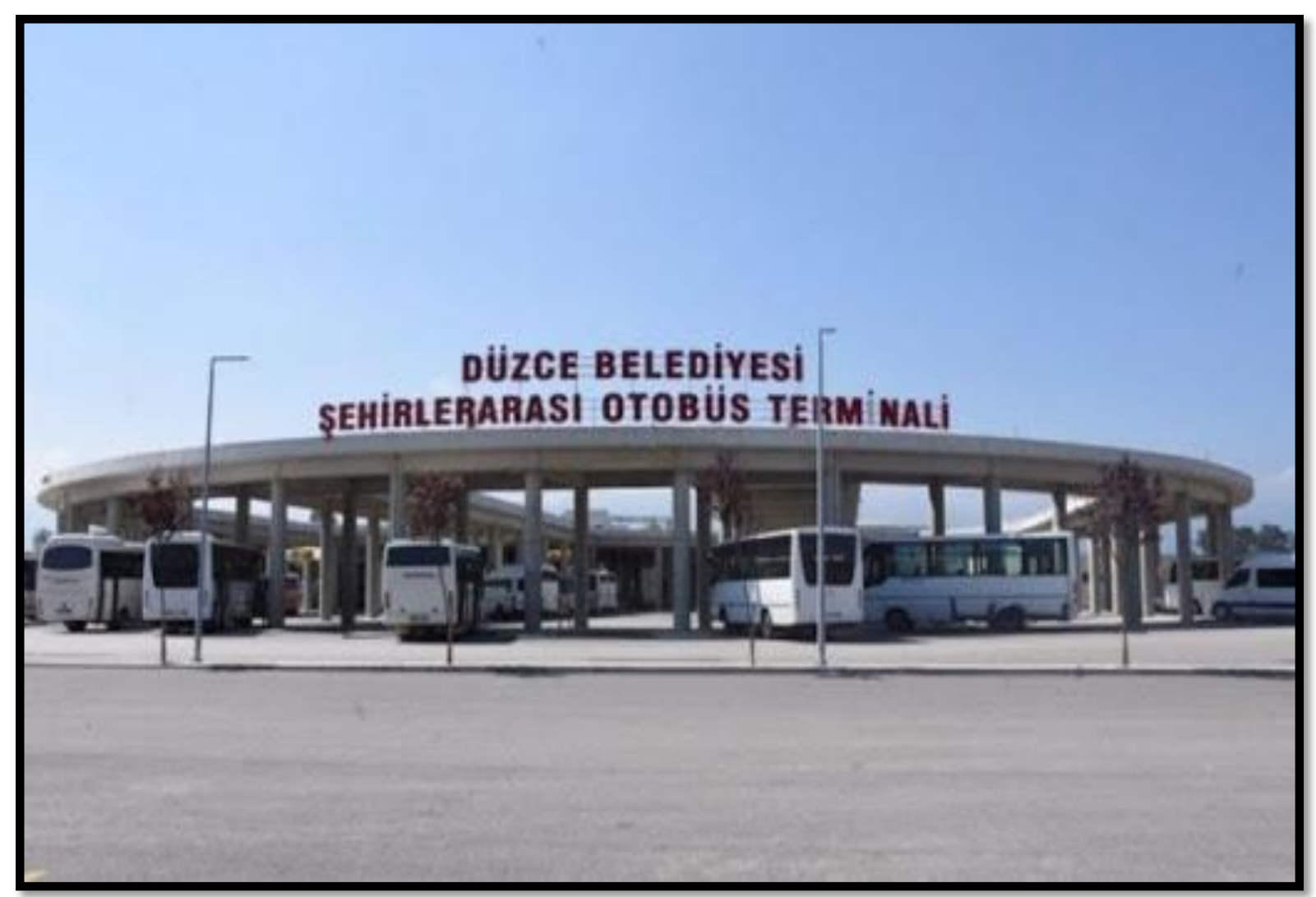

Şekil 4. Düzce Şehirler Arası Otobüs Terminali Orijinal, 2019.

Düzce'de 2016 yılında kentin 50 yıllık ihtiyacını karşılamak amacıyla Darıcı mahallesinde 31 bin 500 metrekare üzerine kurulan ve inşaat alan 7 bin 118 metrekare olan şehirler arası otobüs terminali, 4 bin metrekare de yeşil alana sahiptir. Düzce'nin merkez TEM Otoyol bağlantısının kolay, düzenli bir şekilde sağlanması ve yolcu sirkülasyonunda rahatlama olması için tasarlanmış, eskisine göre daha modern bir hale bürünmesi amaçlanmıştır [9].Terminaller kentlerin turist karşılama mekanları olarak değerlendirilebilecek alanlarıdır. Düzce İli'nde de kente son yıllarda kazandırılan modern terminal uygulamasının birçok sebepten ötürü yarım kalmışlı ve betonarme bir kütle şeklinde soğuk bir görüntüsü mevcuttur. Bu alanda dikey bahçe uygulamasının verimli olabileceği fikri mevcut yeşil alanın eksikliğini gidermek, karşılama görevini üstlenen mekana yeşille görsellik katmak, kentin tanıtımı açısından sembolik tasarımlarla beton kütle görünümdeki yapının daha sıcak ve sempatik hale gelmesini sağlamak amaçlanmıştır. 

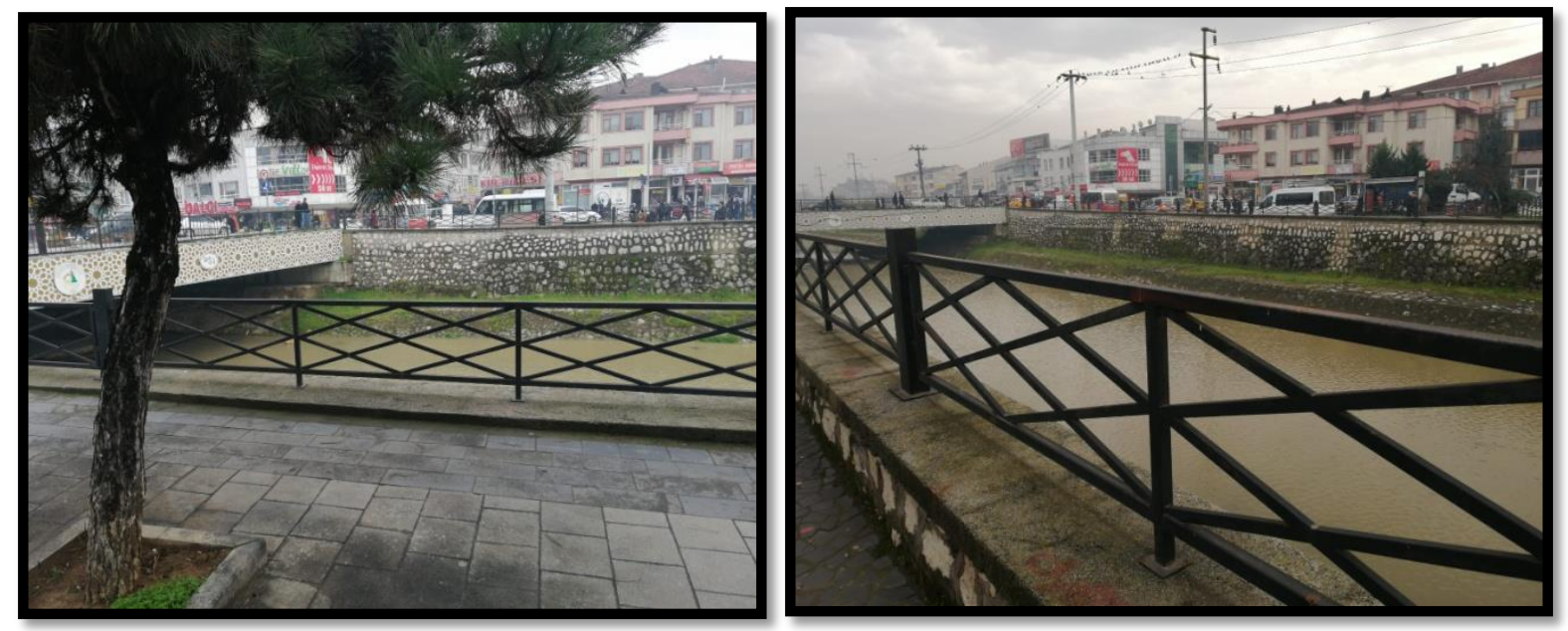

Şekil 5. Asar Deresi Orijinal, 2019.

Düzce'nin yaklaşık 10 km batısında Mamure köyü yakınlarında Küçük Melen'le birleşen Asar Deresi Bolu dağlarında doğar, Kaynaşlı'dan geçerek Üçköprü'de ovaya girer ve batıya doğru akarak birleşim noktasından sonra Küçük Melen içinde Efteni gölüne dökülür. Asar suyunun uzunluğu yaklaşık 30 km, yağış alanı $176 \mathrm{~km}^{2}$ kadardır ve yıllık ortalama akımı 93x16 m³'tür [9].Kent merkezinden geçen Asar Deresi kent insanları tarafından günlük yol geçişi olarak en çok kullanılan alanlardan biridir. Bu alanda dikey bahçe uygulamasının verimli olabileceği fikri mevcut su kenarının duvarlarında var olan kötü görüntüyü gidermek, orada bulunan çay bahçesi, iş yerleri, oturma alanlarına suyla beraber bütünlük kazandırarak yeşilin maviyle doğal görüntüsünü oluşturma amaçlanmıştır.

\section{B. YÖNTEM}

Çalışmanın amacına uygun olacak şekilde Düzce İli’ni simgeleyecek tasarımlar oluşturulmuş ve bu tasarımlar önce iki boyutlu ardından da üç boyutlu şekilde tasarlanarak uygulanması öngörülen alanlara bilgisayar programlarıyla yerleştirilmiştir. Bu tasarımlar seçilen üç ayrı alanda, üç farklı uygulama şekli (bitkilerden oluşan dikey bahçeler, plastik objelerden oluşan dikey bahçeler, konuşan duvarlar) olarak 100 kişiden oluşan anketle kullanıcılara sunulmuştur.

Yapılan anket iki kısımdan ve toplamda 10 sorudan oluşmaktadır. İlk kısım katılımcıların belirleyici özelliklerini tanımlamak için, ikinci kısım ise oluşturulan tasarımların kullanılan materyallere göre şıklar halinde sunularak hangi sıfat çiftlerinin tercih edildikleri gözlemlenmiştir. Katılımcıların yaşları, cinsiyetleri, medeni durumları, eğitim düzeyleri, meslekleri, gelir düzeyleri ve Düzce'de ikamet ediş yılları ilk kısımdaki değişkenleri oluşturmaktadır. İkinci kısımda üç farklı (bitkilerden oluşan dikey bahçeler, plastik objelerden oluşan dikey bahçeler, konuşan duvarlar) materyalden oluşturulan dikey bahçeler; yapay-doğal, estetik-estetik değil, yorucu-dinlendirici, uyumlu-uyumsuz, karışık-anlaşlır, sıradanlık hissi-modern sıfat çiftleriyle katılımcıların görsel peyzaj tercihleri belirlenmeye çalışılıış̧ır. Eskiz çalışmalarıyla oluşturulan tasarımlar, AutoCad-2019 programıla iki boyutlu olarak bilgisayar ortamına alınmış ve SketchUp 2019 ile Lumion6.0 programları kullanılarak üç boyutlu hale getirilmiştir. 


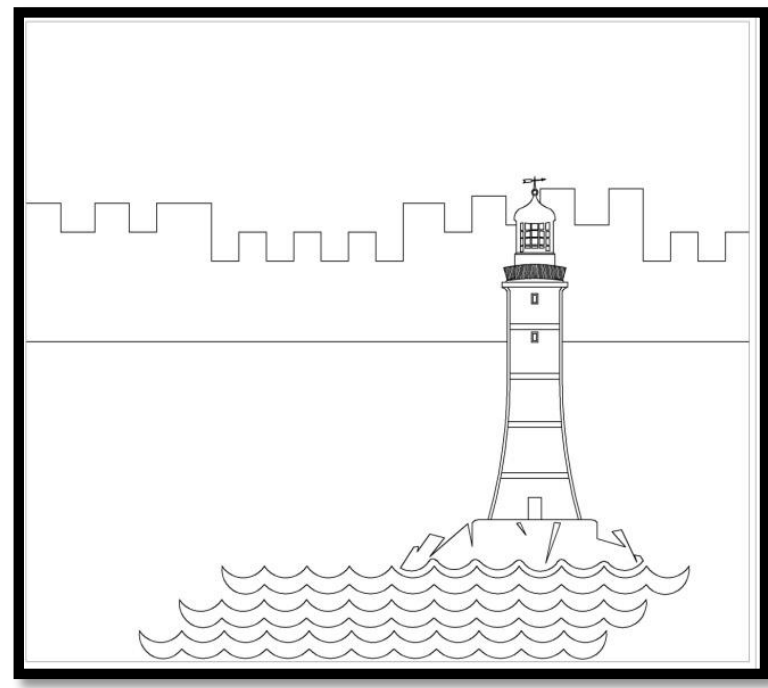

Şekil 6. 1.Tasarım: Akçakoca İlçesi.

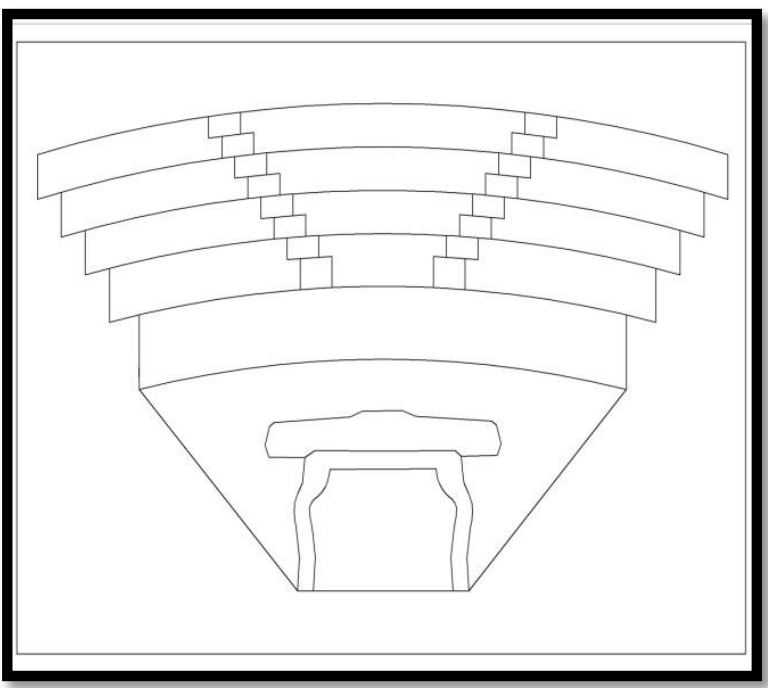

Şekil 8. 3.Tasarım: Konuralp İlçesi.

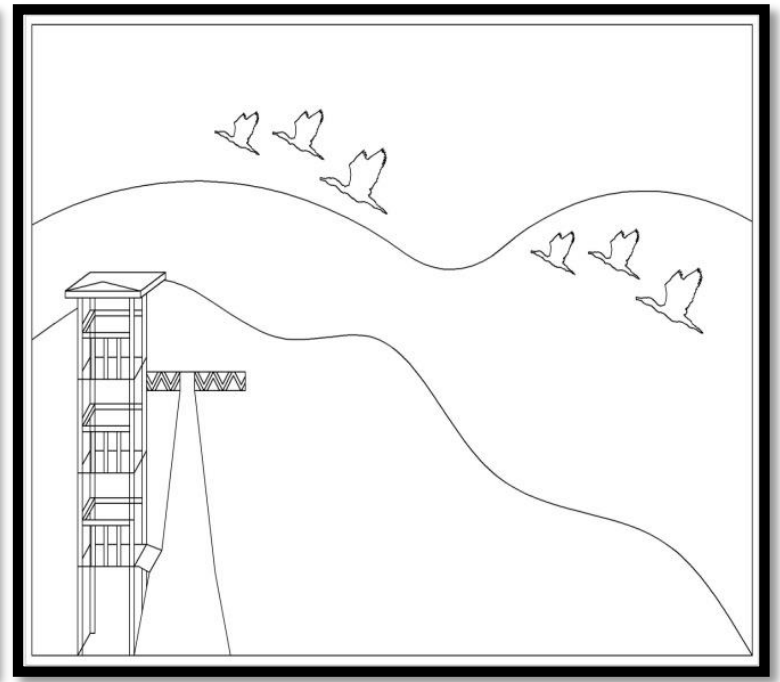

Şekil 7. 2.Tasarım: Efteni Gölü.

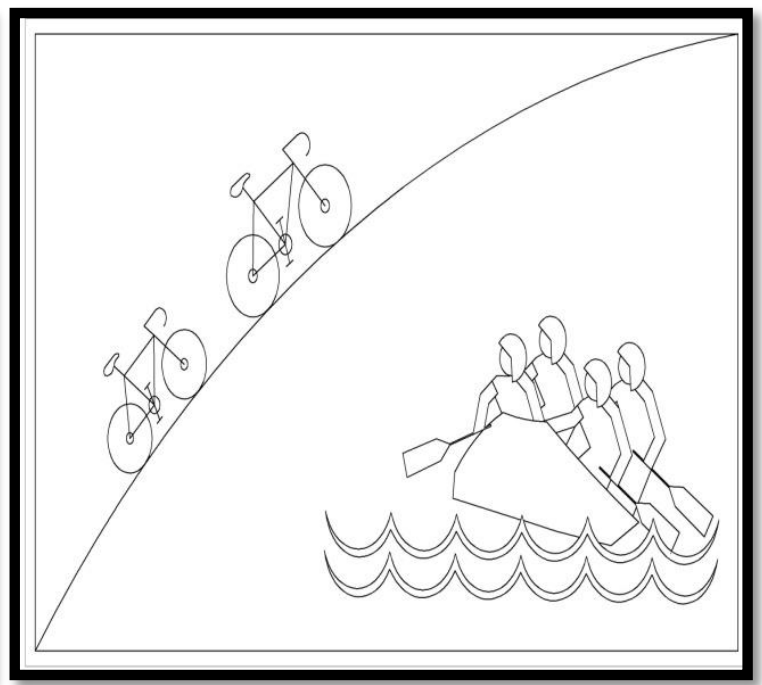

Şekil 9. 4.Tasarım: Yapılan Sporlar.

Tasarımlar, kentin kimliğini oluşturabilecek simgelerden esinlenerek yapılmıştır. İlk tasarımda Düzce'nin denize kıyısı olan Akçakoca ilçesi tasvir edilmiş olup, orada bulunan Ceneviz Kalesi ve deniz feneri simgeleştirilmiştir. Kentin kültürel, doğal ve tarihi turizm bölgesi olan ilçe kenti tanımlayan bir figür olarak kullanılmıştır. İkinci tasarımda Efteni Gölü tasvir edilmiş ve doğal güzelliği, kuş türlerinin göç alanı oluşu, göle dair bir çok efsanevi hikayelerinin de yaygınlığıyla her daim kentlinin uğrak yeri olan bu alan da kent kimliğinde bir figür olarak kullanılmıștır. Düzce'nin medeniyetlere ev sahipliği yapmış olan ilçesi Konuralp günümüzde hala kazı çalışmaları devam eden Prusias Antik Kenti, sit alanı özelliği taşıyan, tarihi turizm kimliğiyle olmazsa olmaz bir figür olarak tasarımlarda kullanılmıştır.

Kent insanının ulaşımda en çok kullandığı bisikletler ve rafting sporu da kenti tanımlayan bir figür olarak kullanılmıştır.

Tasarımlarda kullanılan figürler, kentin tanıtımında kullanılan yerlerin arasından seçilmiş ve hem belediye çalışanları hem de kentlilere sorularak son karar verilmiştir. Bu alanlar Düzce ile özdeşleşmiş alanlar olup kent kimliğinde tanıtım rolü üstlenmiş yerlerdir.

Yapılan tasarımlar, seçilen alanlarda üç farklı uygulama örneği olarak sunulmuştur. Bunlar; yalnızca bitkilerden oluşan dikey bahçeler, plastik objelerden oluşturulan dikey bahçeler ve boyanarak elde edilen konuşan duvarlar şeklinde meydana getirilmiştir. Son dönemlerde dikey bahçelerin kaldırılıp yerlerine alternatif çalışmaların uygulanması sebebiyle bu çalışmada cansız materyallerden oluşan 
tasarımlar da kullanıcının fikrine sunulmuştur. Farklı tasarım uygulamaları kullanıcıların görsel peyzaj tercihinin hangi yönde olduğunu belirlemek amacıyla tercih için kullanılmıştır.

Literatürde sıfat çiftleri olumlu olumsuz olarak sınıflandırılmıştır [10] ve bu sebeple anket çalışmasında da sıfatlar böyle şekillendirilmiştir. Sıfat çiftlerinin aynı zamanda tasarım ve görsel güç açıdan ikiye ayrıldığı belirlenmiştir [11]. Bu çalışmada kullanılan sıfat çiftleri; yapay-doğal, estetik-estetik değil, uyumlu-uyumsuz, karışık-anlaşılır, modern-sıradanlık hissi olarak olumlu ve olumsuz olarak sıralanmıştır.

Çalışma kapsamında elde edilen anketler SPSS paket programıla katılımcıların sosyo-ekonomik durumları sıklık (frequencies) analiziyle belirlenmiştir. Katılımcı özelliklerin etkisi ve görsel değişkenler, sıfat özellikleri ile arasındaki ilişkinin belirlenmesi amacıyla standart sapma ve aritmetik ortalamaları alınmıştır. Katılımcıların kullanılan materyale göre beğenileri arasında anlamlı bir fark olup olmadığını incelemek amacıyla tekrarlı ölçümler anova testi yürütülmüştür. Çalışma da sözel ve görsel değerler rakamsal ifadeler olarak ele alınarak sayısal değerler olarak değerlendirilmiştir.

\section{III.BULGULAR VE TARTISMA}

\section{A. ANKET SONUCUNDA ÇOBAN DALÇIK İÇİN ELDE EDİLEN BULGULAR}

Anketi yerli halk ve iş, okul sebebiyle kentte yaşamını sürdüren katılımcıların cevaplarına göre analiz ettiğimizde her bir bölge için elde ettiğimiz sonuçlarda;

\section{A. 1.Bitkilerden Oluşturulan Dikey Bahçe Tasarım}

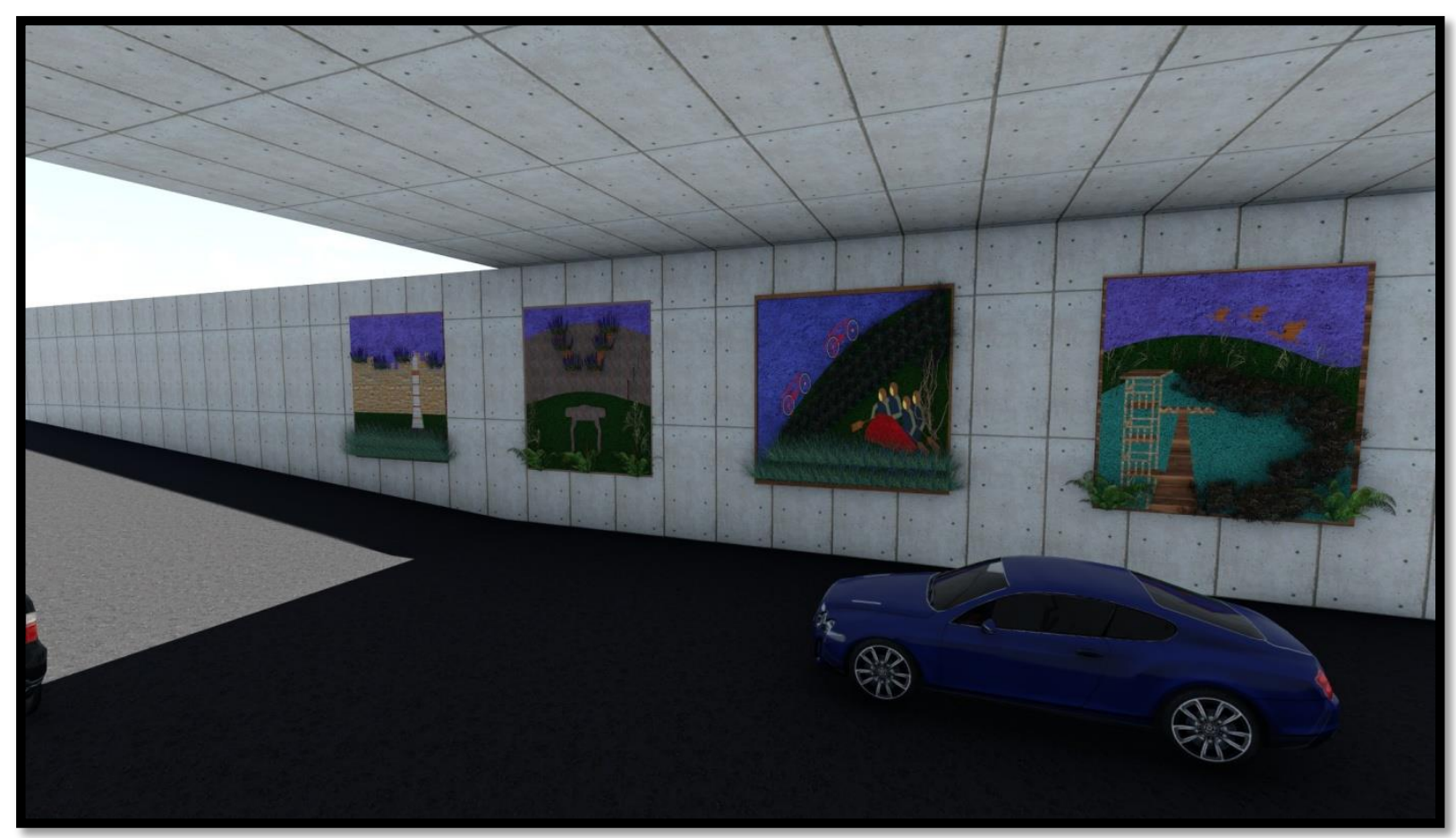

Şekil 10. Çoban Dalçık Duvarlarında Oluşturulan Üç Boyutlu Bitkisel Tasarım. 

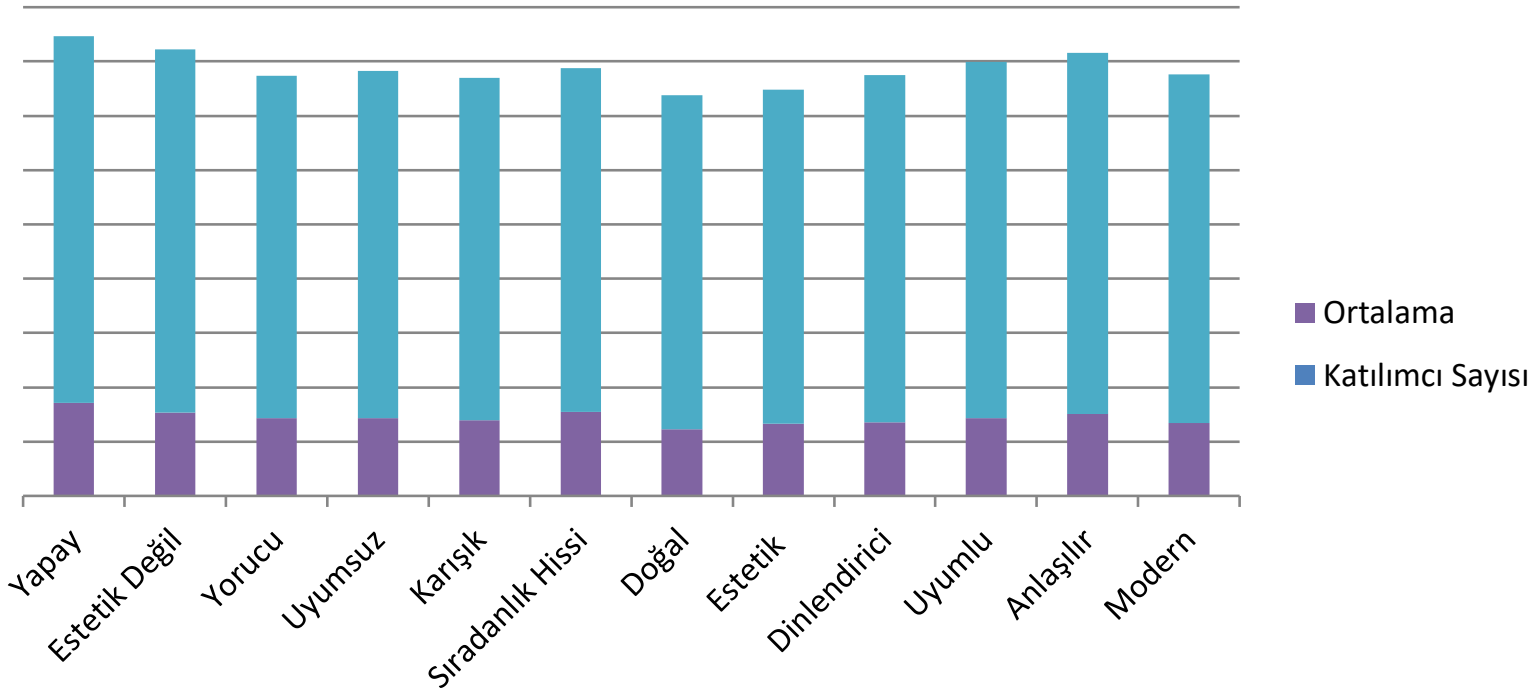

Şekil 11.Çoban Dalçık Duvarlarında Bitkisel Tasarım Açısından Değerlendirme Grafiği.

Katılımcılar; yapay-doğal, estetik-estetik değil, uyumlu-uyumsuz, karışık-anlaşılır, modern-sıradanlık hissi kriterlerinden oluşan sorularda alan için oluşturulan 4 ayrı tasarımın bitkisel halini modern ve estetik bulmuşlardır.

\section{A. 2. Plastik Objelerden Oluşturulan Dikey Bahçe Tasarım}

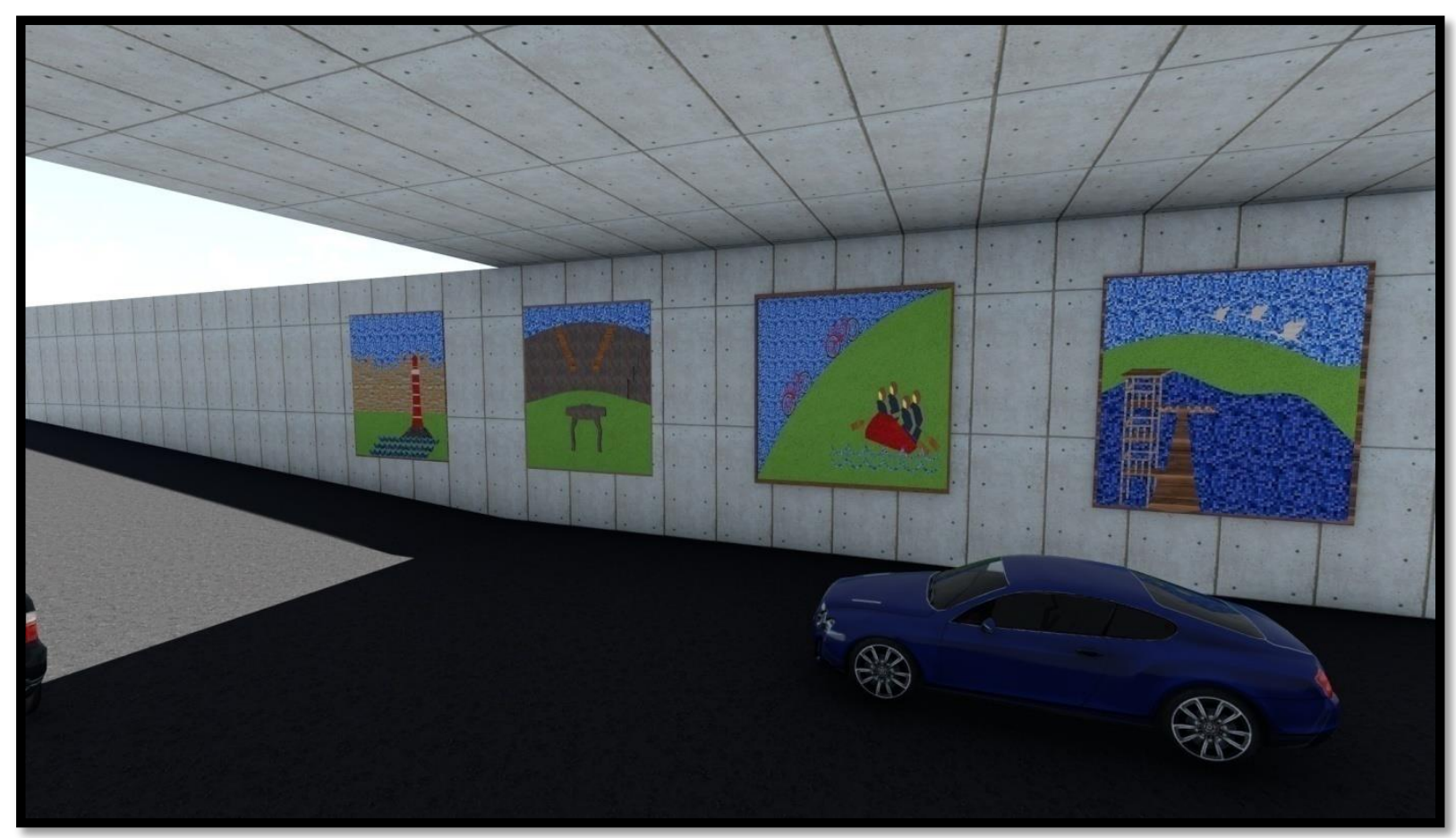

Şekil 12. Çoban Dalçık Duvarlarında Oluşturulan Üç Boyutlu Plastik Obje Tasarım. 

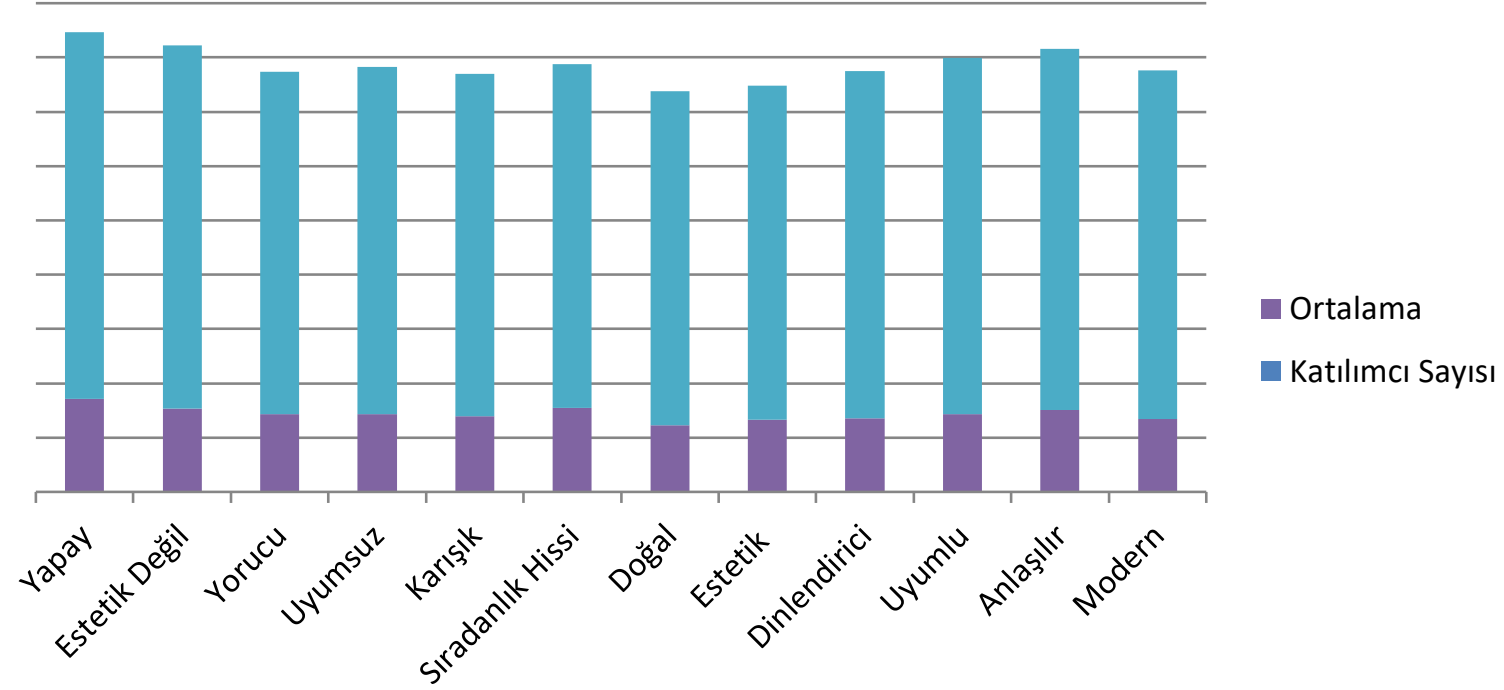

Şekil 13. Çoban Dalçık Duvarlarında Plastik Obje Tasarım Açısından Değerlendirme Grafiği.

Katılımcılar; yapay-doğal, estetik-estetik değil, uyumlu-uyumsuz, karışık-anlaşılır, modern-sıradanlık hissi kriterlerinden oluşan sorularda alan için oluşturulan 4 ayrı tasarımın bitkisel halini estetik değil ve yorucu bulmuşlardır.

\section{A. 3. Konuşan Duvar Olarak Oluşturulan Dikey Bahçe Tasarım}

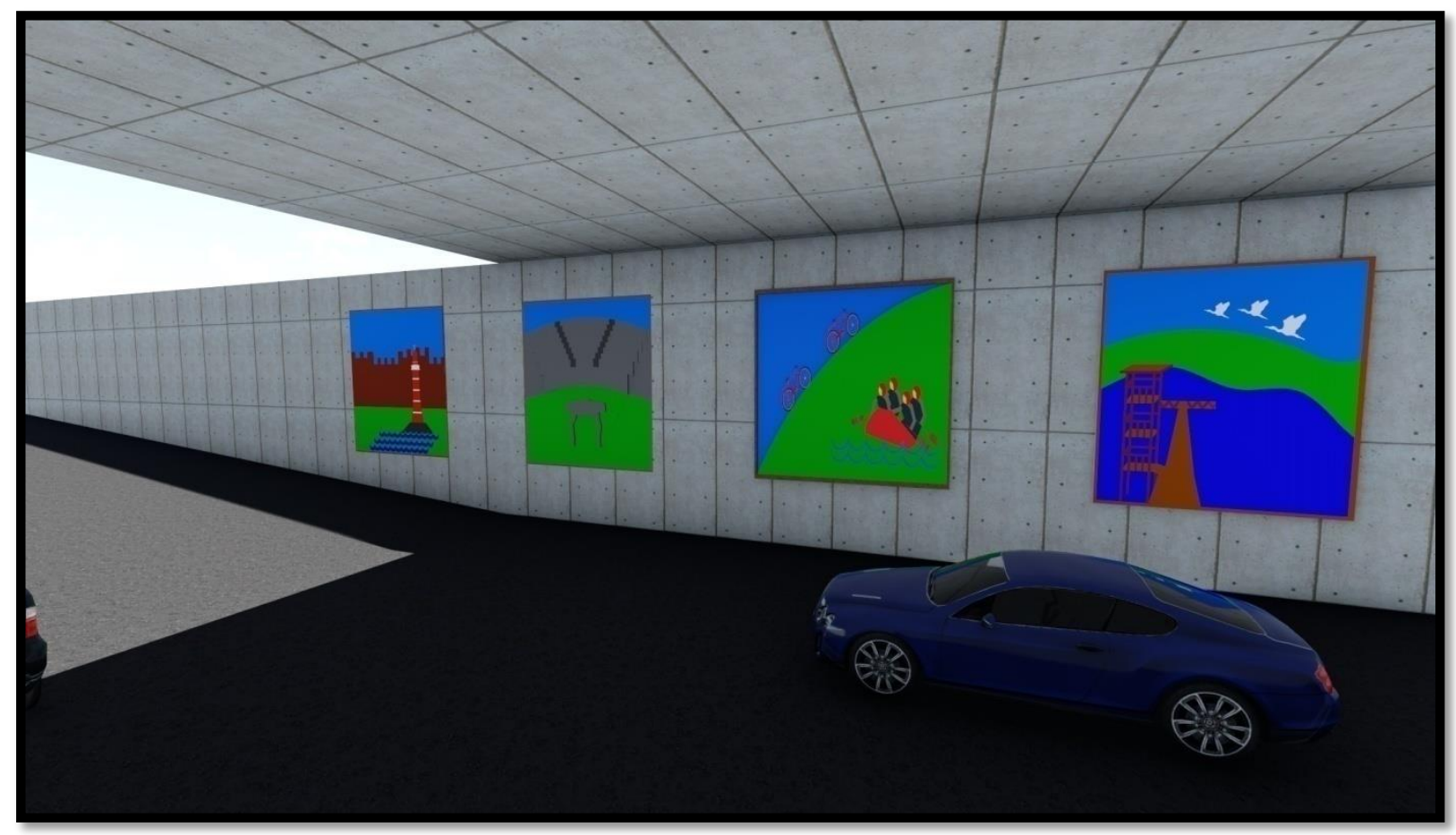

Şekil 14. Çoban Dalçık Duvarlarında Oluşturulan Üç Boyutlu Konuşan Duvar Tasarımı. 

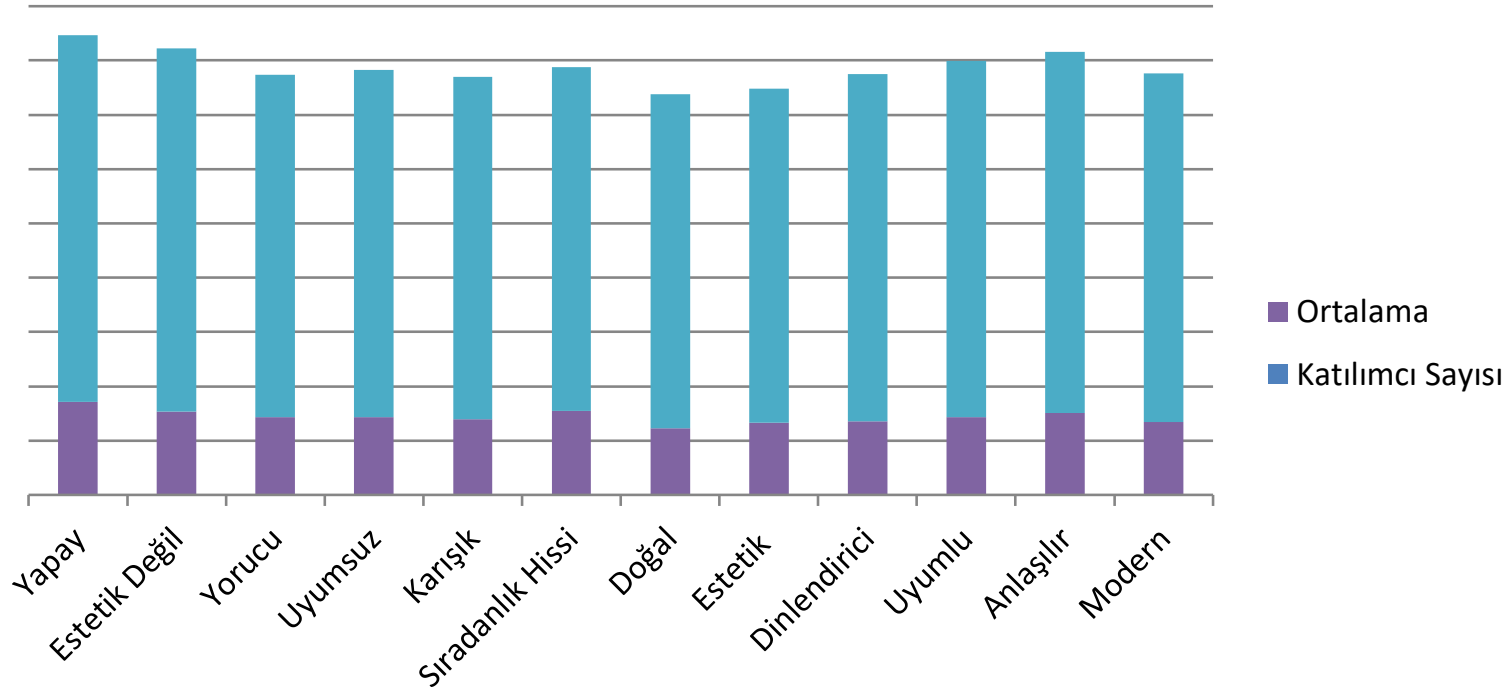

Şekil 15. Çoban Dalçık Duvarlarında Konuşan Duvar Tasarım Açısından Değerlendirme Grafiği.

Katılımcılar; yapay-doğal, estetik-estetik değil, uyumlu-uyumsuz, karış1k-anlaşılır, modern-sıradanlık hissi kriterlerinden oluşan sorularda alan için oluşturulan 4 ayrı tasarımın bitkisel halini estetik değil ve yapay bulmuşlardır.

\section{B. ANKET SONUCUNDA ŞEHIRLER ARASI OTOBÜS TERMIINALİ İÇİN ELDE EDILEN BULGULAR}

Anketi yerli halk ve iş, okul sebebiyle kentte yaşamını sürdüren katılımcıların cevaplarına göre analiz ettiğimizde her bir bölge için elde ettiğimiz sonuçlarda;

\section{B. 1. Bitkilerden Oluşturulan Dikey Bahçe Tasarım}

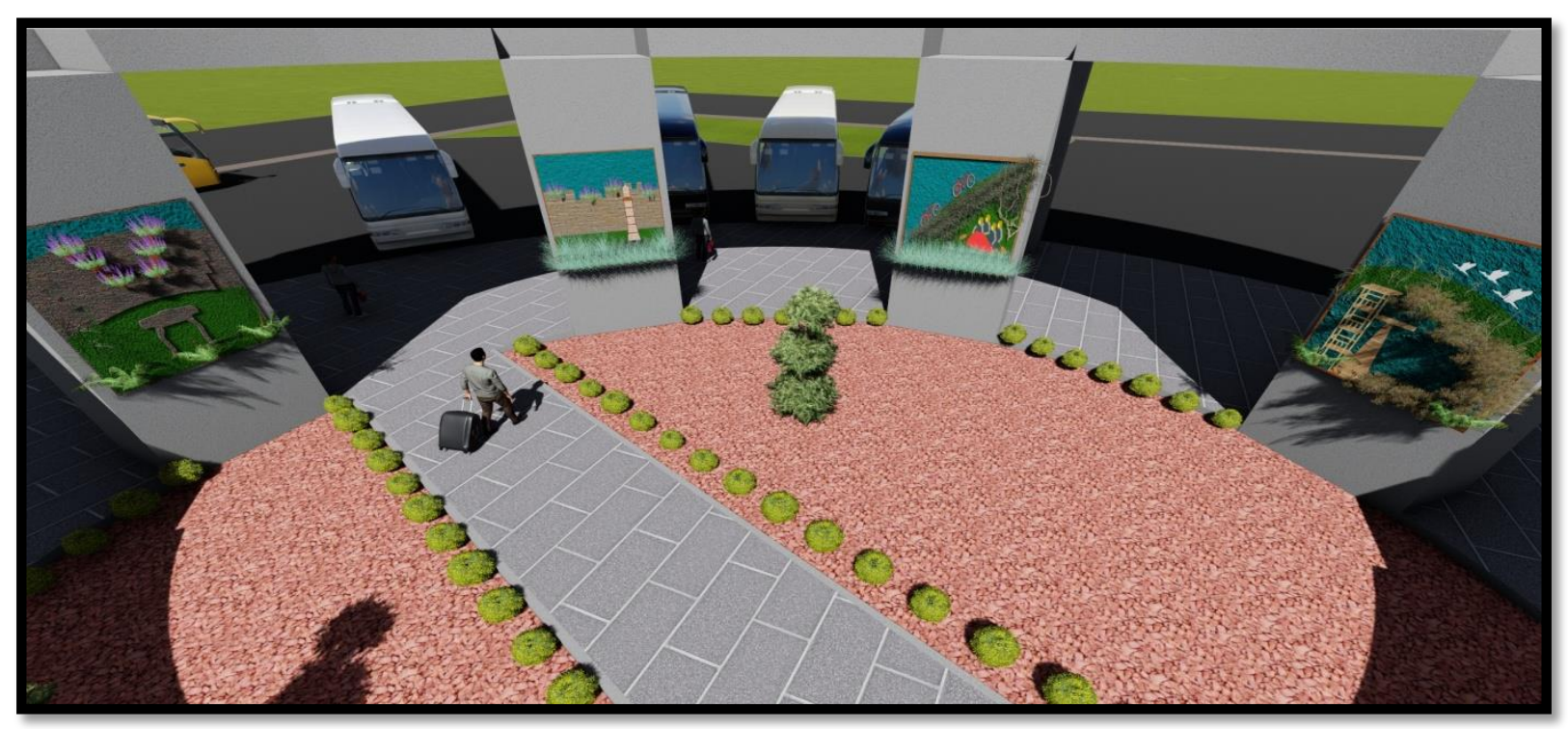

Şekil 16. Şehirler Arası Otobüs Terminali Duvarlarında Oluşturulan Ü̧̧ Boyutlu Bitkisel Duvar Tasarımı. 

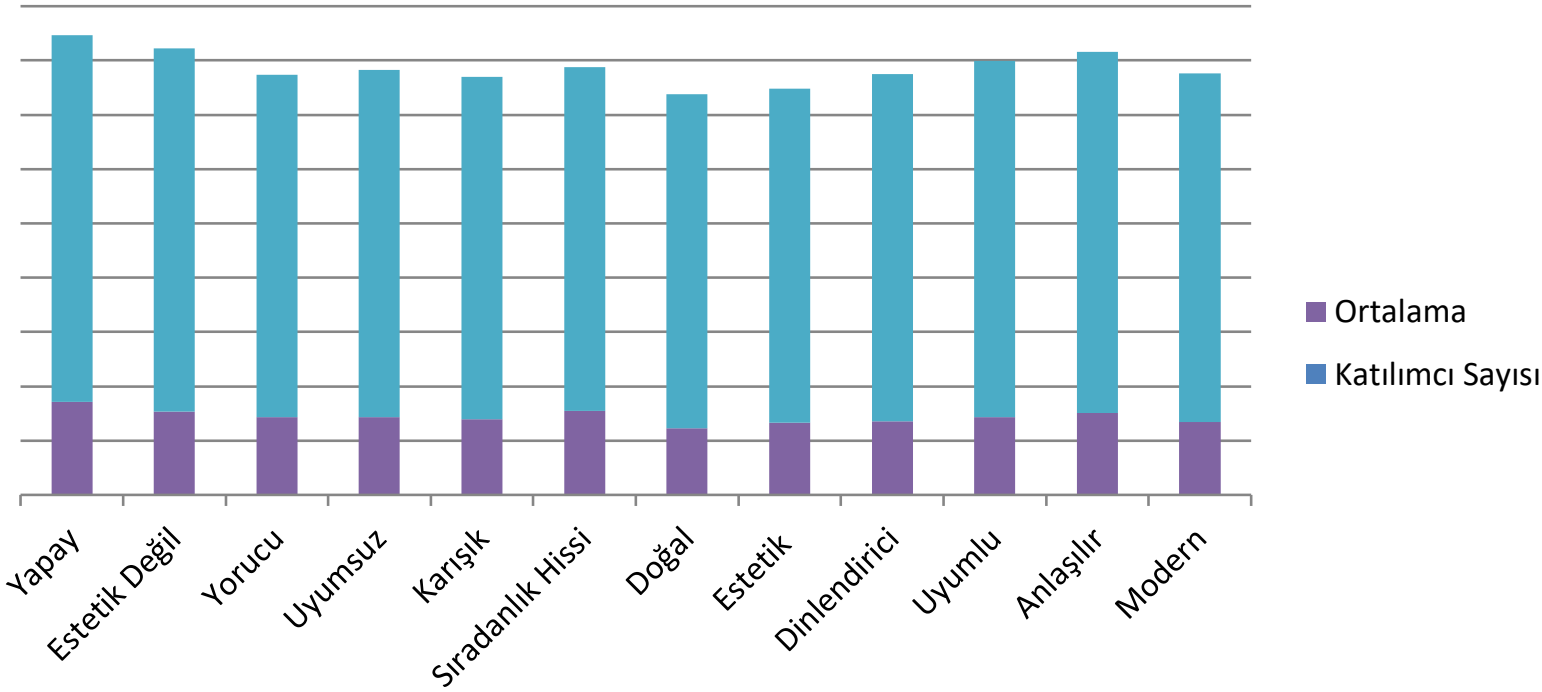

Şekil 17. Şehirler Arası Otobüs Terminali Duvarlarında Bitkisel Tasarım Açısından Değerlendirme Grafiği.

Katılımcılar; yapay-doğal, estetik-estetik değil, uyumlu-uyumsuz, karışık-anlaşılır, modern-sıradanlık hissi kriterlerinden oluşan sorularda alan için oluşturulan 4 ayrı tasarımın bitkisel halini modern ve estetik bulmuşlardır.

\section{B. 2. Plastik Objelerden Oluşturulan Dikey Bahçe Tasarım}

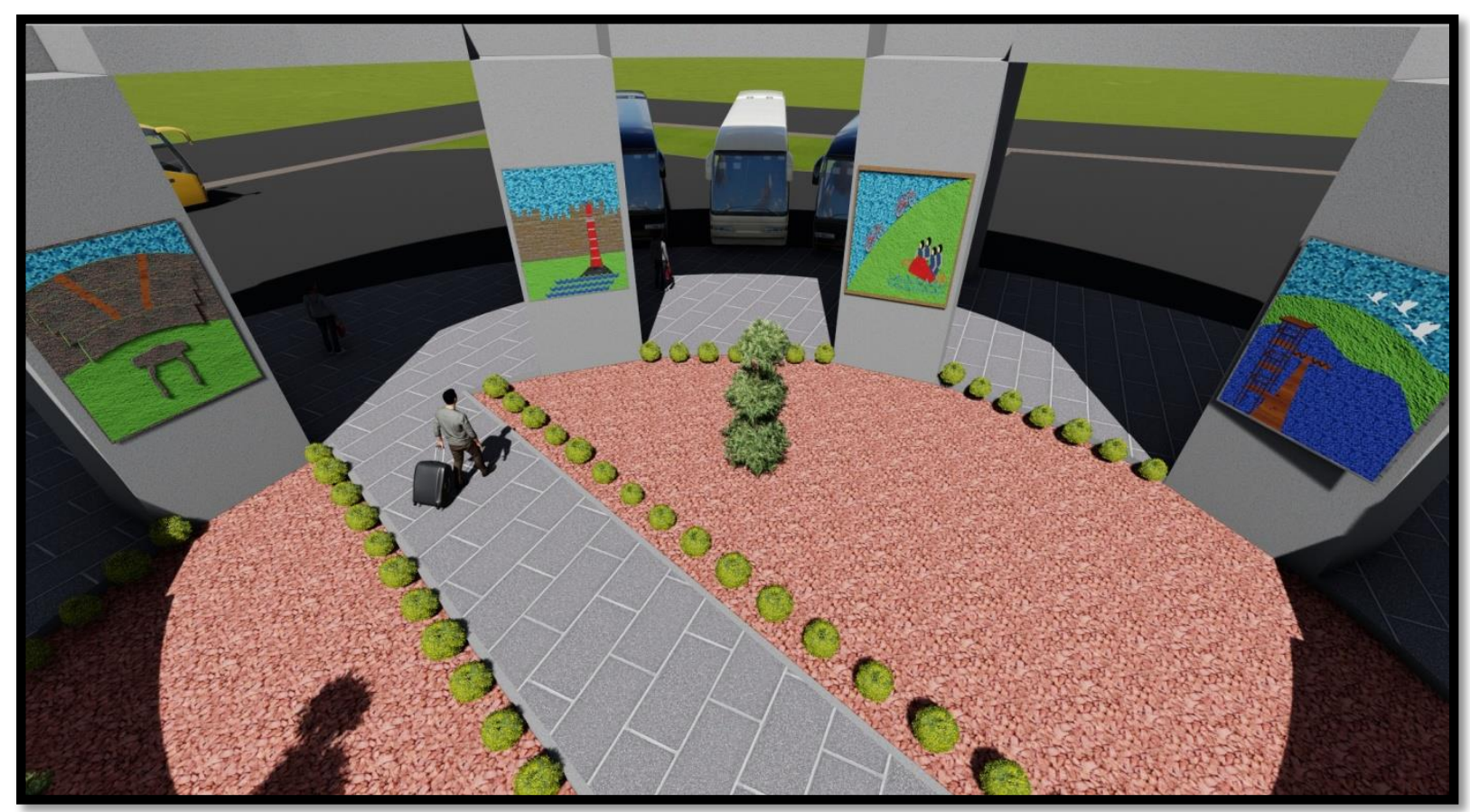

Şekil 18. Şehirler Arası Otobüs Terminali Duvarlarında Oluşturulan Üç Boyutlu Plastik Obje Tasarımı. 

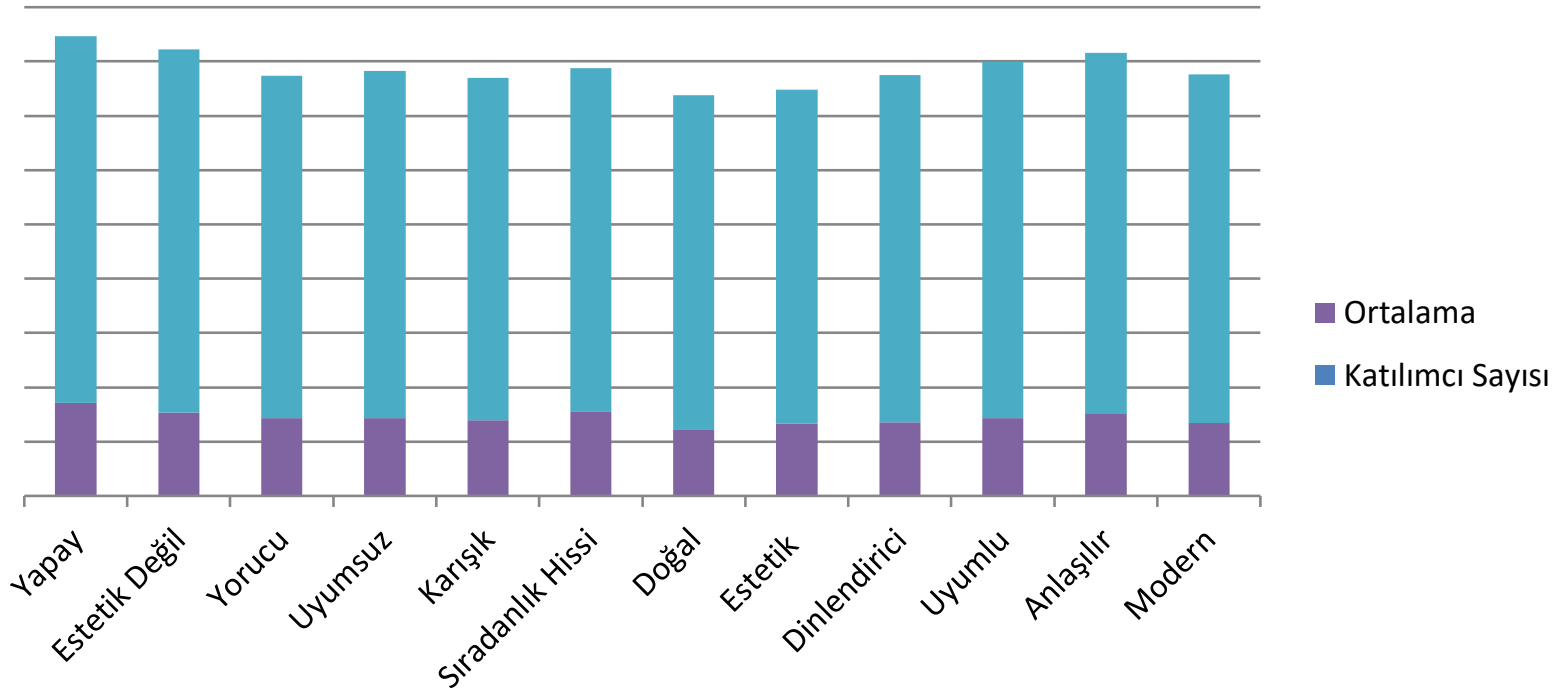

Şekil 19.Şehirler Arası Otobüs Terminali Duvarlarında Plastik Obje Tasarım Açısından Değerlendirme Grafiği.

Katılımcılar; yapay-doğal, estetik-estetik değil, uyumlu-uyumsuz, karışık-anlaşılır, modern-sıradanlık hissi kriterlerinden oluşan sorularda alan için oluşturulan 4 ayrı tasarımın bitkisel halini estetik değil ve yorucu bulmuşlardır.

\section{B. 3. Konuşan Duvar Olarak Oluşturulan Dikey Bahçe Tasarım}

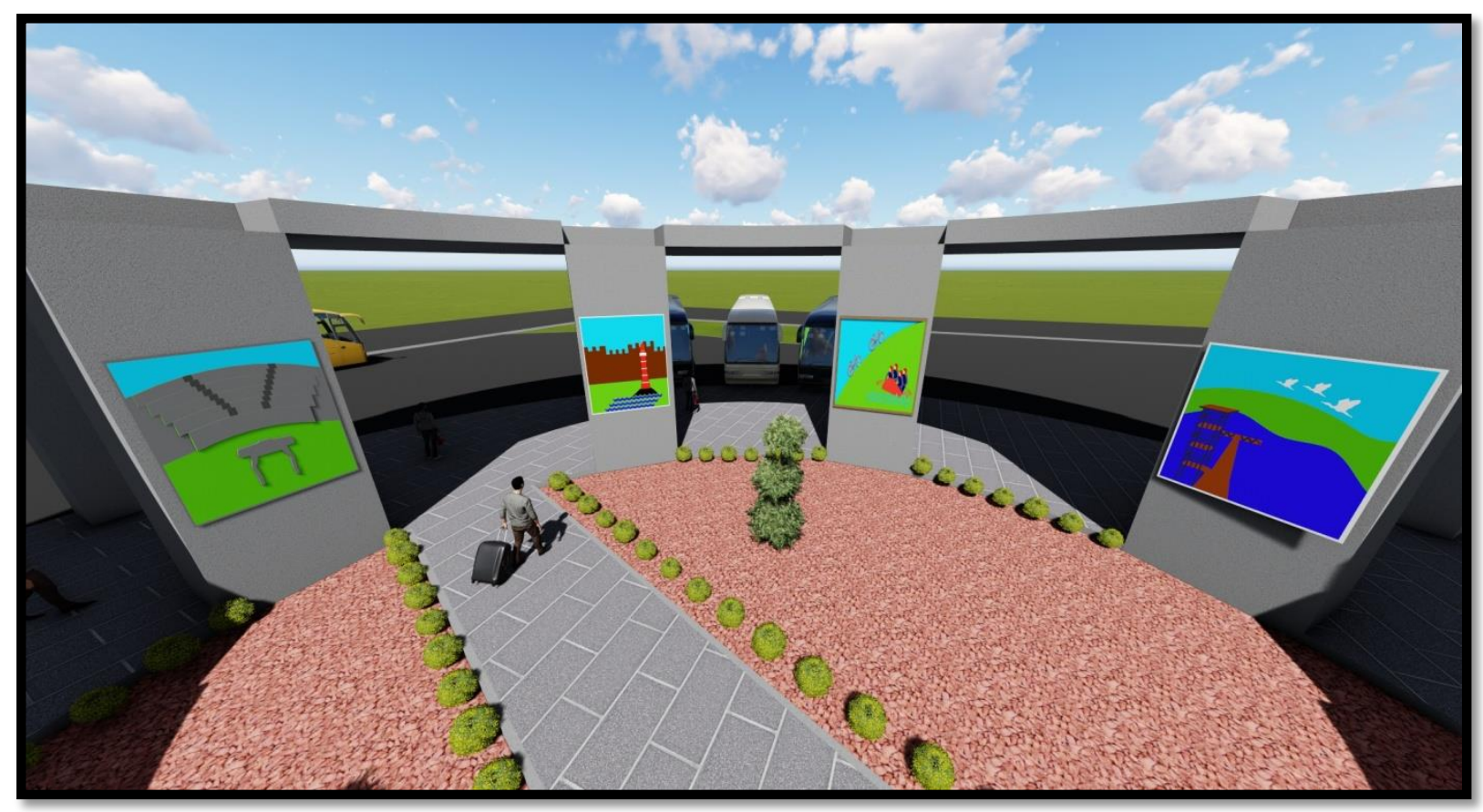

Şekil 20. Şehirler Arası Otobüs Terminali Duvarlarında Oluşturulan Üç Boyutlu Konuşan Duvar Tasarımı. 

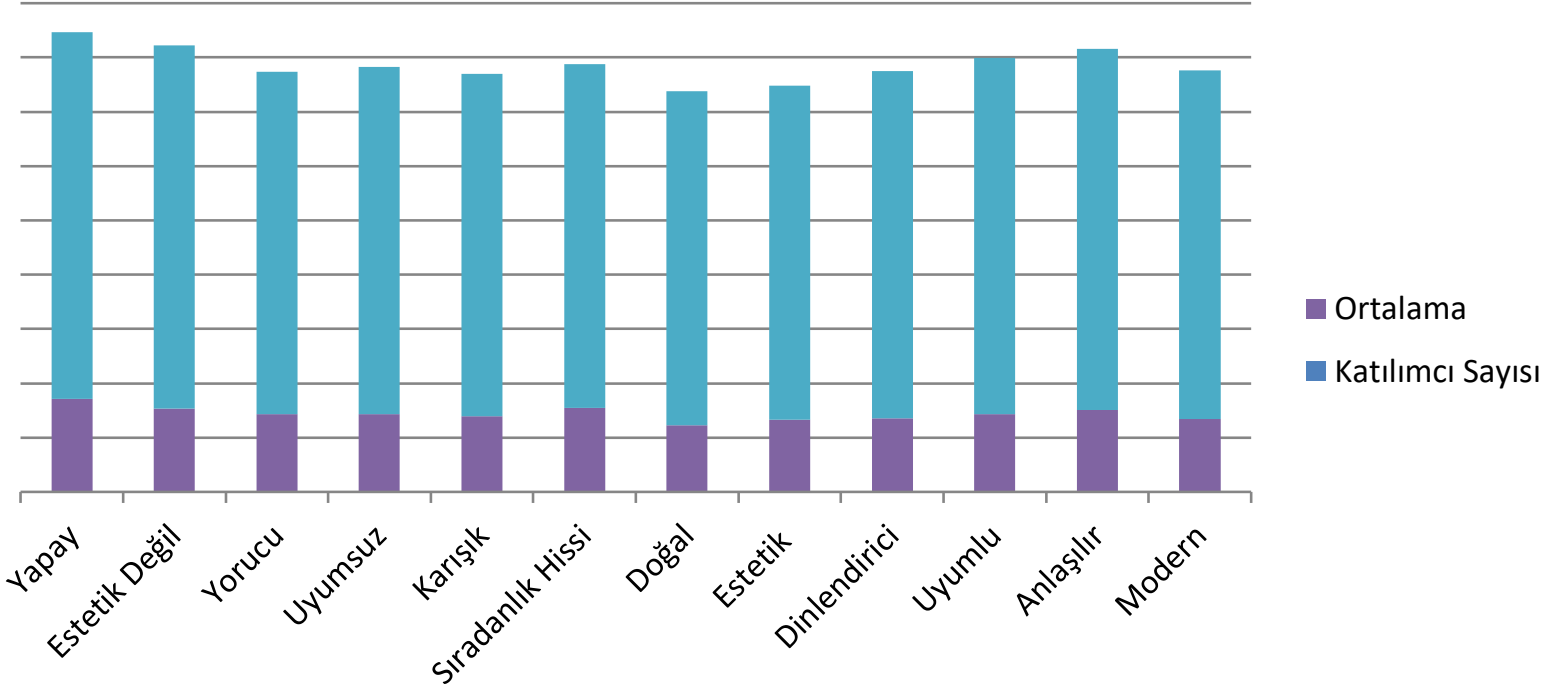

Şekil 21. Şehirler Arası Otobüs Terminali Duvarlarında Konuşan Duvar Tasarım Açısından Değerlendirme Grafiği.

Katılımcılar; yapay-doğal, estetik-estetik değil, uyumlu-uyumsuz, karışık-anlaşılır, modern-sıradanlık hissi kriterlerinden oluşan sorularda alan için oluşturulan 4 ayrı tasarımın bitkisel halini estetik değil ve yapay bulmuşlardır.

\section{ANKET SONUCUNDA ASAR DERESİ İÇİN ELDE EDİLEN BULGULAR}

Anketi yerli halk ve iş, okul sebebiyle kentte yaşamını sürdüren katılımcıların cevaplarına göre analiz ettiğimizde her bir bölge için elde ettiğimiz sonuçlarda;

\section{1. Bitkilerden Oluşturulan Dikey Bahçe Tasarım}

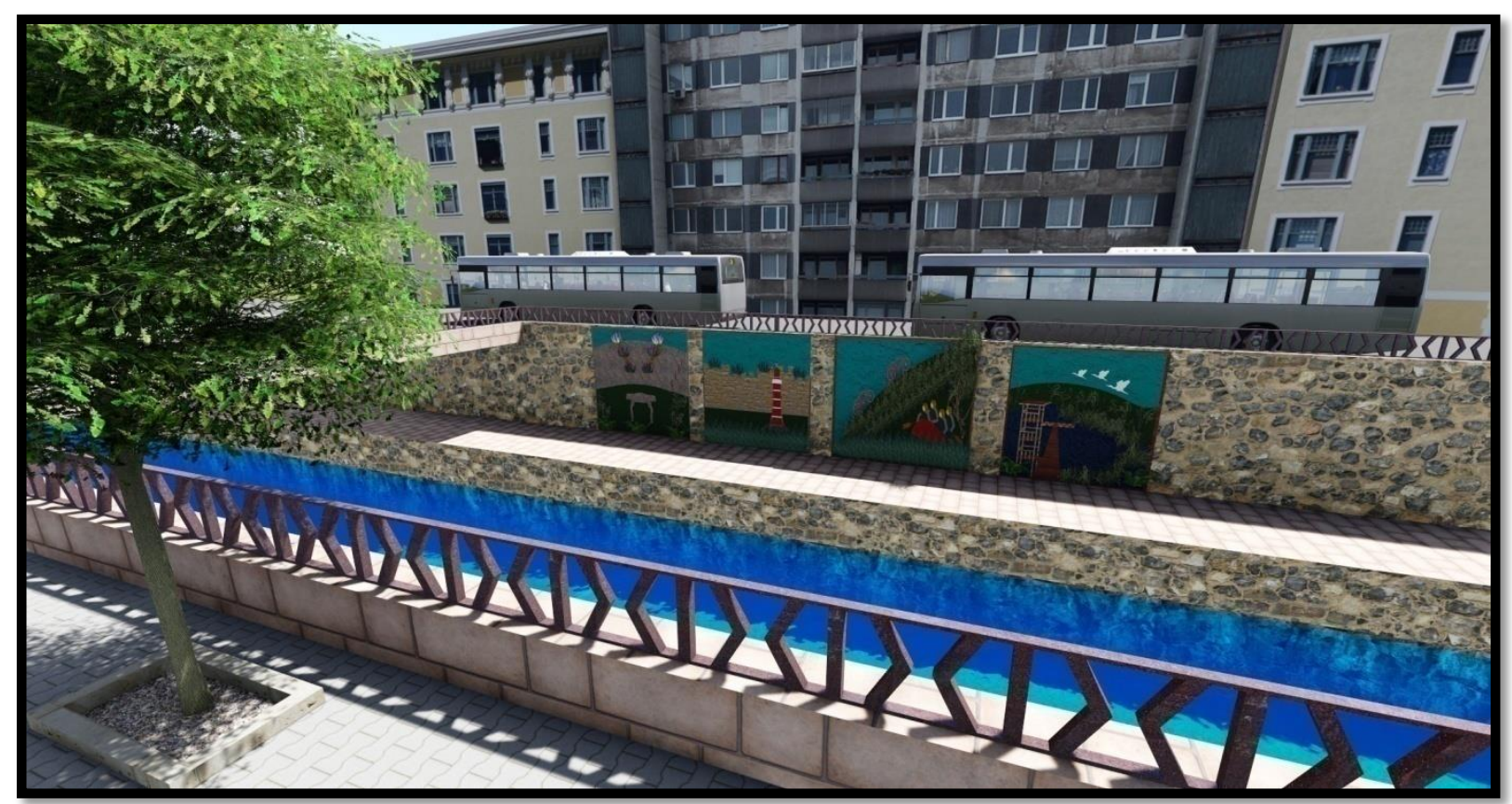

Şekil 22. Asar Deresi Duvarlarında Oluşturulan Üç Boyutlu Bitkisel Duvar Tasarımı. 

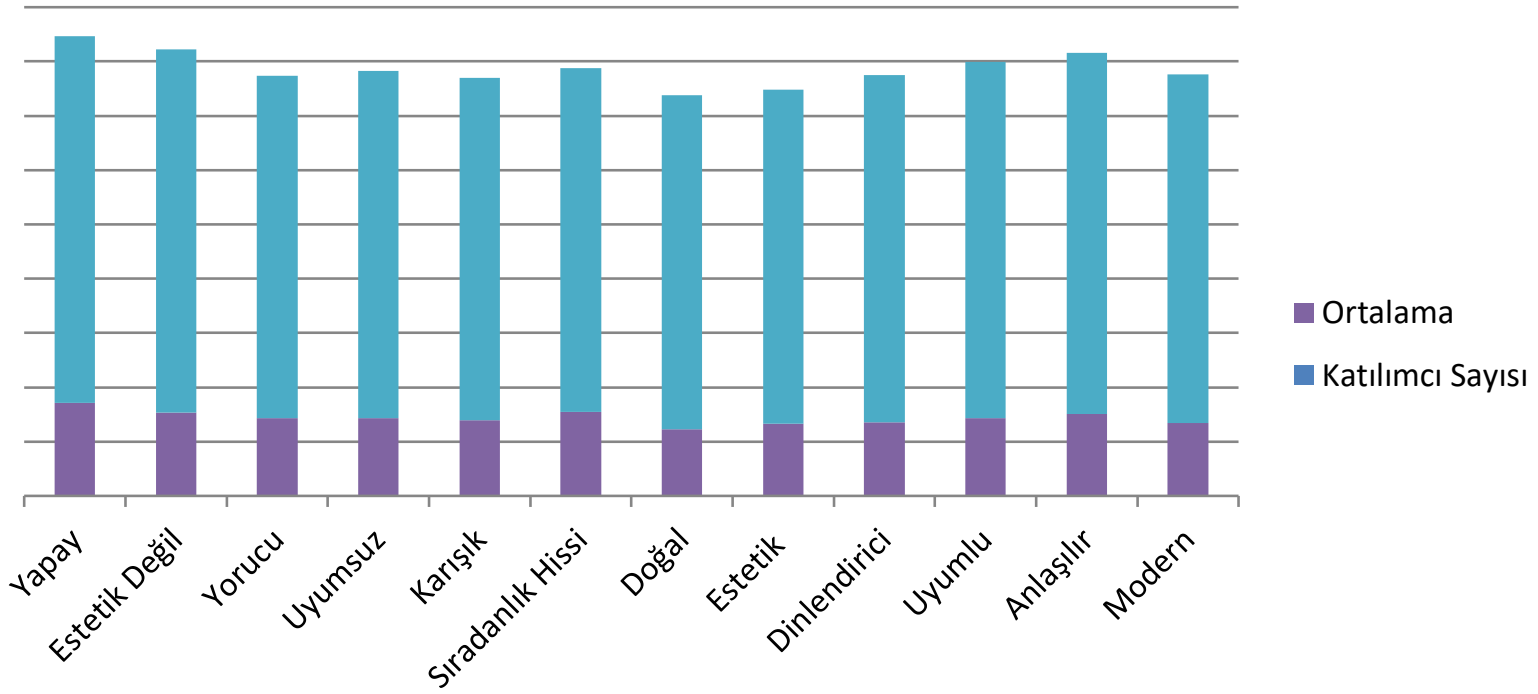

Şekil 23. Asar Deresi Duvarlarında Bitkisel Tasarım Açısından Değerlendirme Grafiği.

Katılımcılar; yapay-doğal, estetik-estetik değil, uyumlu-uyumsuz, karışık-anlaşılır, modern-sıradanlık hissi kriterlerinden oluşan sorularda alan için oluşturulan 4 ayrı tasarımın bitkisel halini modern ve estetik bulmuşlardır.

\section{2. Plastik Objelerden Oluşturulan Dikey Bahçe Tasarım}

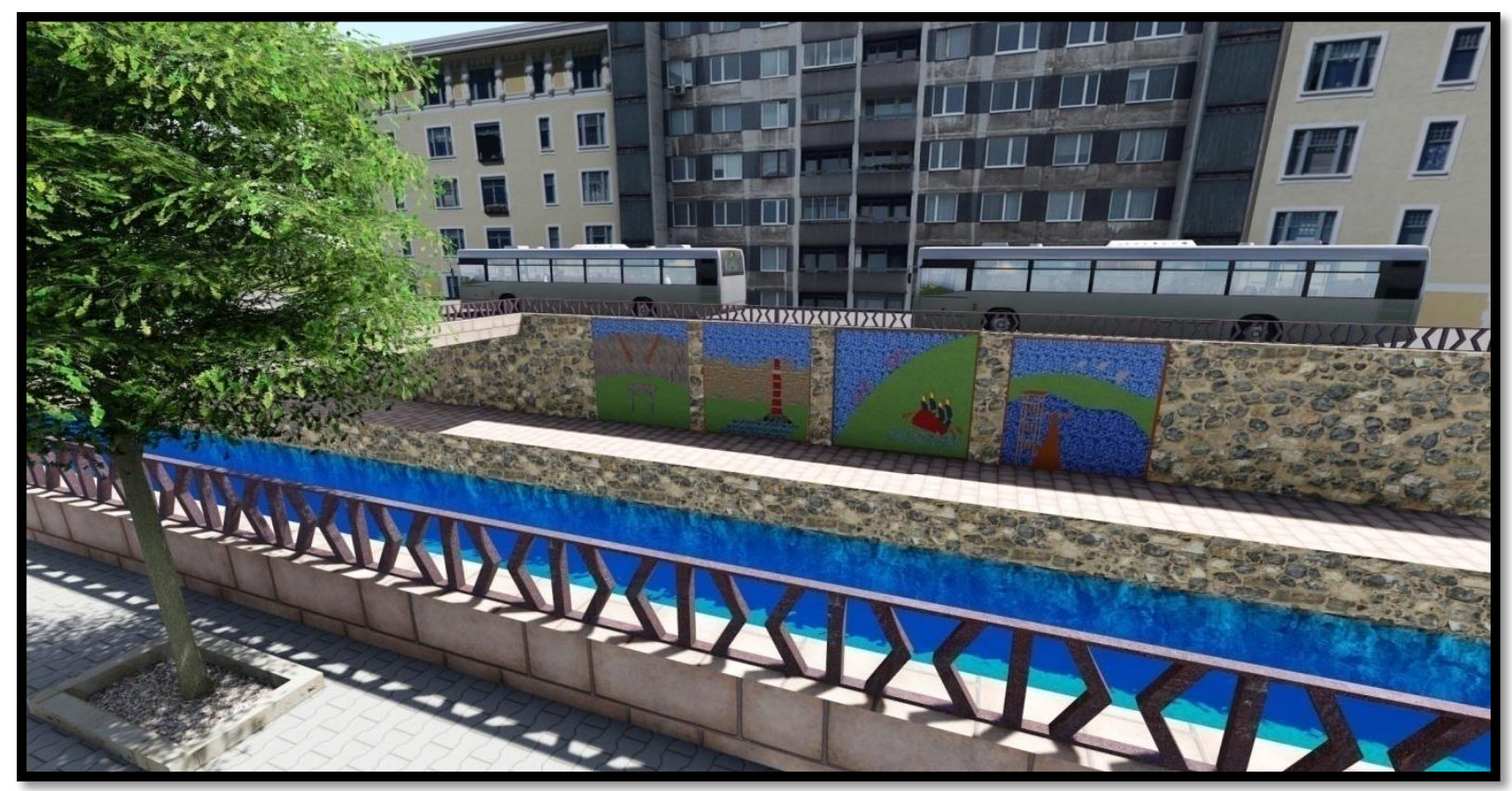

Şekil 24. Asar Deresi Duvarlarında Oluşturulan Üç Boyutlu Plastik Obje Tasarımı. 

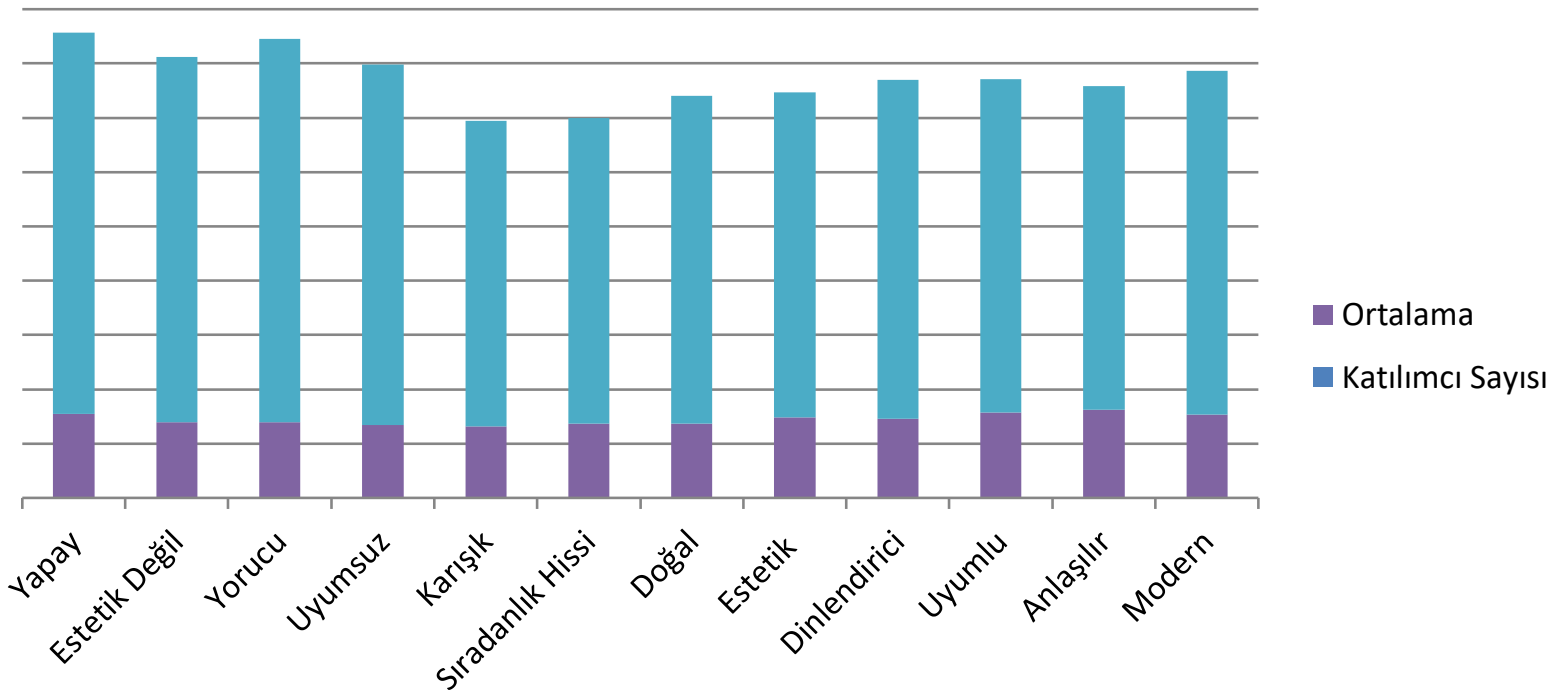

Şekil 25. Asar Deresi Duvarlarında Plastik Obje Tasarım Açısından Değerlendirme Grafiği.

Katılımcılar; yapay-doğal, estetik-estetik değil, uyumlu-uyumsuz, karışık-anlaşılır, modern-sıradanlık hissi kriterlerinden oluşan sorularda alan için oluşturulan 4 ayrı tasarımın bitkisel halini estetik değil ve yorucu bulmuşlardır.

\section{3. Konuşan Duvar Olarak Oluşturulan Dikey Bahçe Tasarım}

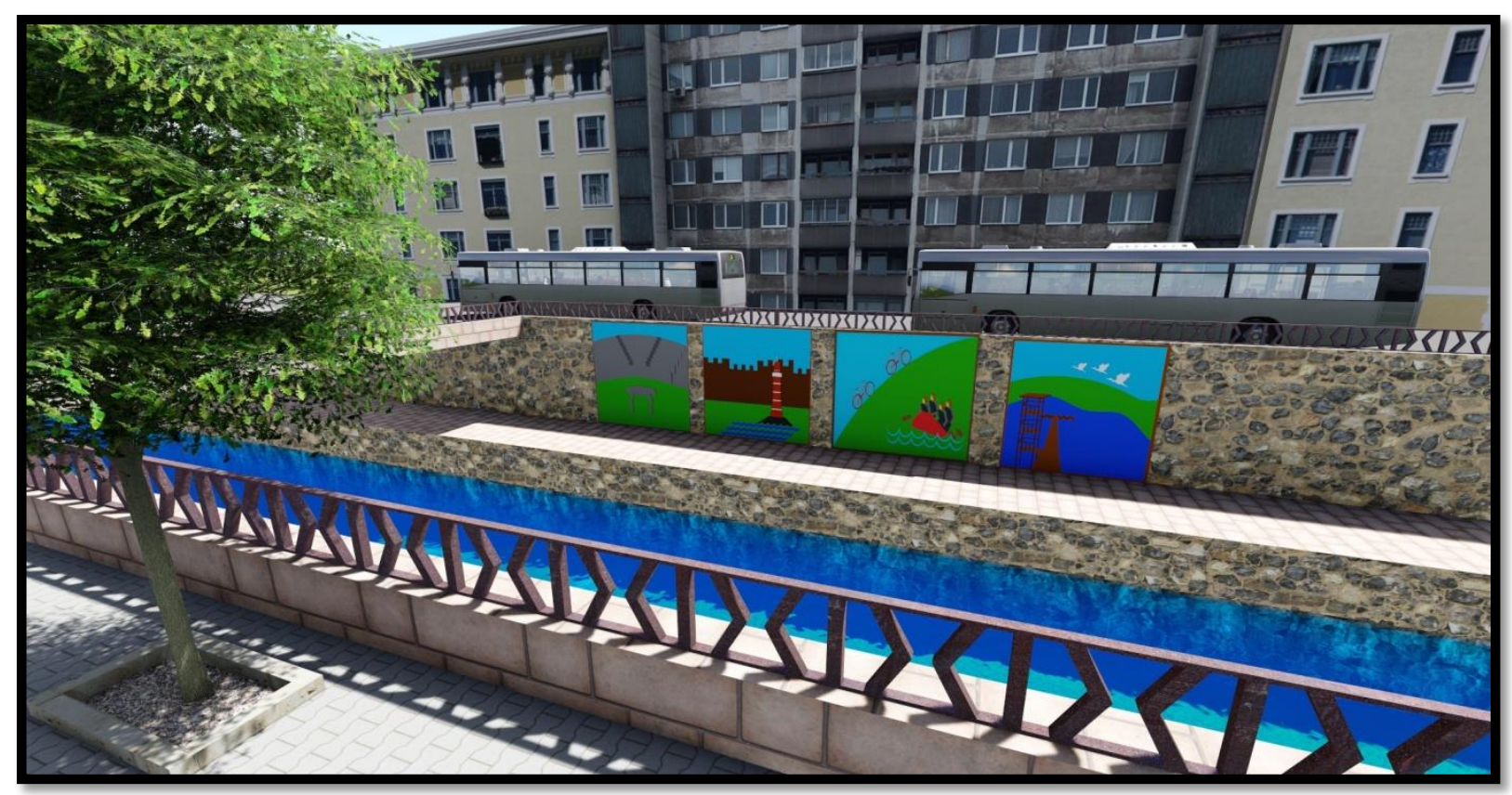

Şekil 26. Asar Deresi Duvarlarında Oluşturulan Üç Boyutlu Konuşan Duvar Tasarımı. 


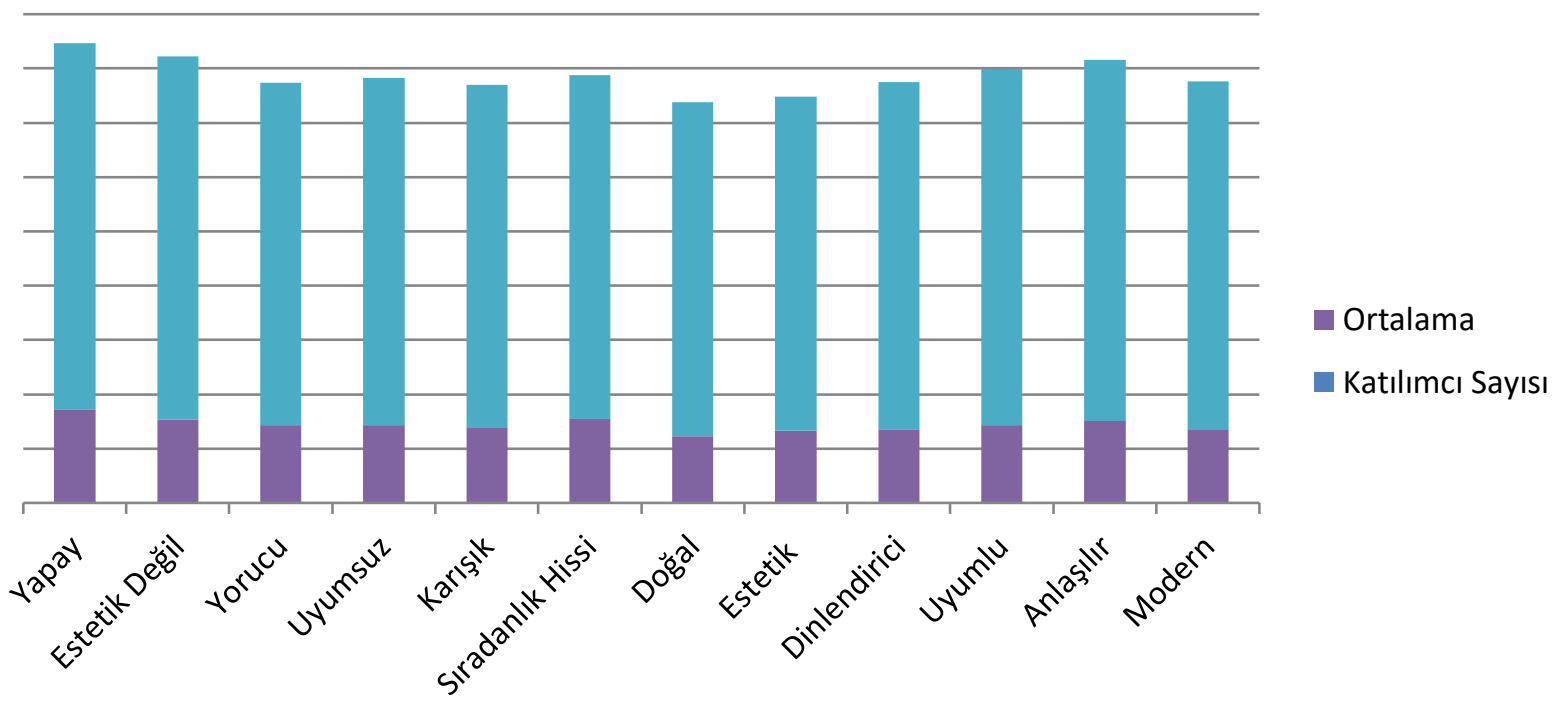

Şekil 27. Asar Deresi Duvarlarında Konuşan Duvar Tasarım Açısından Değerlendirme Grafiği.

Katılımcılar; yapay-doğal, estetik-estetik değil, uyumlu-uyumsuz, karışık-anlaşılır, modern-sıradanlık hissi kriterlerinden oluşan sorularda alan için oluşturulan 4 ayrı tasarımın bitkisel halini estetik değil ve yapay bulmuşlardır.

Gizemli peyzajlar bulundukları ortamlarda güçlü peyzaj hissi yaratan ve çok sayıda parça sunan heterojen peyzajlardır [12].Heterojen peyzajlar sıradanlık hissinden uzak, modern yapılar sunma algis1 yaratır. Yapılan tasarımlar "modern-sıradanlık hissi" sıfat çiftine göre değerlendirildiğinde; bitkisel malzemelerden ve plastik malzemeler kullanılarak oluşturulan dikey bahçeler katılımcılar tarafından modern bulunmuştur.

Doğallık kavramı bitki, kaya, su gibi elemanların bir peyzajdaki bütünlüğü olarak tanımlanmıştır [13]. Ancak bir alanda insan yapısı elemanlar yoğunluk olarak fazlaysa ve doğal elemanlar o alanda yapay elemanlara göre baskın duruyorsa, alan "peyzaj" olarak tanımlanabiliyorsa bu tür alanlar kullanımları gereği yapaylıklarına rağmen doğal olarak algılanmaktadır [14]. Yapılan tasarımlar "doğal-yapay" sıfat çiftine göre değerlendirildiğinde; bitkisel malzemelerden oluşturulan dikey bahçeler katılımcılar tarafından doğal bulunmuştur.

Tablo 1. Dikey Bahçe Tasarımlarında Üç Farklı Alana Uygulanan Üç Farklı Malzemenin Slfat Çiftleri Yönünden Ortalamalarının Değerlendirme Tablosu.

\begin{tabular}{|c|c|c|c|c|c|c|}
\hline \multirow[t]{2}{*}{ SIFATLAR } & \multicolumn{2}{|c|}{ BITKIISEL TASARIM } & \multicolumn{2}{|c|}{$\begin{array}{l}\text { PLASTÍK OBJE } \\
\text { TASARIM }\end{array}$} & \multicolumn{2}{|c|}{$\begin{array}{l}\text { KONUŞAN DUVAR } \\
\text { TASARIM }\end{array}$} \\
\hline & $\begin{array}{l}\text { Aritmetik } \\
\text { Ortalama }\end{array}$ & $\begin{array}{l}\text { Standart } \\
\text { Sapma }\end{array}$ & $\begin{array}{l}\text { Aritmetik } \\
\text { Ortalama }\end{array}$ & $\begin{array}{l}\text { Standart } \\
\text { Sapma }\end{array}$ & $\begin{array}{l}\text { Aritmetik } \\
\text { Ortalama }\end{array}$ & $\begin{array}{l}\text { Standart } \\
\text { Sapma }\end{array}$ \\
\hline YAPAY & 2,0546 & ,94329 & 3,0843 & 1,24081 & 3,4227 & 1,39186 \\
\hline $\begin{array}{l}\text { ESTETİK } \\
\text { DEĞİL }\end{array}$ & 1,9969 & ,93435 & 2,8475 & 1,18810 & 3,0982 & 1,35180 \\
\hline YORUCU & 1,9468 & ,89778 & 2,7696 & 1,20879 & 2,9042 & 1,27785 \\
\hline UYUMSUZ & 2,0237 & ,91465 & 2,7160 & 1,16672 & 2,9331 & 1,30380 \\
\hline
\end{tabular}


Tablo 1(devam). Dikey Bahçe Tasarımlarında Ü̧̧ Farklı Alana Uygulanan Ü̧̧ Farklı Malzemenin Sifat Çiftleri Yönünden Ortalamalarının Değerlendirme Tablosu.

\begin{tabular}{|c|c|c|c|c|c|c|}
\hline \multirow[t]{2}{*}{ SIFATLAR } & \multicolumn{2}{|c|}{ BİTKİSEL TASARIM } & \multicolumn{2}{|c|}{$\begin{array}{l}\text { PLASTIK OBJE } \\
\text { TASARIM }\end{array}$} & \multicolumn{2}{|c|}{$\begin{array}{l}\text { KONUŞAN DUVAR } \\
\text { TASARIM }\end{array}$} \\
\hline & $\begin{array}{l}\text { Aritmetik } \\
\text { Ortalama }\end{array}$ & $\begin{array}{l}\text { Standart } \\
\text { Sapma }\end{array}$ & $\begin{array}{l}\text { Aritmetik } \\
\text { Ortalama }\end{array}$ & $\begin{array}{l}\text { Standart } \\
\text { Sapma }\end{array}$ & $\begin{array}{l}\text { Aritmetik } \\
\text { Ortalama }\end{array}$ & $\begin{array}{l}\text { Standart } \\
\text { Sapma }\end{array}$ \\
\hline KARIŞIK & 2,0702 & ,87592 & 2,6708 & 1,10921 & 2,8025 & 1,21850 \\
\hline $\begin{array}{l}\text { SIRADANLIK } \\
\text { HISSSI }\end{array}$ & 2,0685 & ,91841 & 2,7397 & 1,08687 & 3,0191 & 1,18484 \\
\hline DOĞAL & 3,6824 & 99899 & 2,6736 & 1,12394 & 2,4234 & 1,14719 \\
\hline ESTETIKK & 3,6811 & 99966 & 2,8659 & 1,14634 & 2,6285 & 1,14918 \\
\hline DINLENDİRICİ & 3,6311 & 1,03097 & 2,8250 & 1,17710 & 2,6945 & 1,21327 \\
\hline UYUMLU & 3,7022 & 1,01368 & 3,0026 & 1,18152 & 2,8226 & 1,22758 \\
\hline ANLAŞILIR & 3,7753 & 99580 & 3,1228 & 1,16582 & 3,0008 & 1,24475 \\
\hline MODERN & 3,7443 & 1,04127 & 2,9664 & 1,19517 & 2,7115 & 1,22191 \\
\hline
\end{tabular}

Sifat çiftleri katılımcılar tarafından, farklı alanlarda ve kullanılan her farklı malzemede algısal değişiklikler göstermiştir. Tasarımların uygulanması planlanan üç farklı alanda ve üç farklı malzeme ile;

-Yapay-doğal sifat çifti:

Bitkisel malzemelerle oluşturulan dikey bahçe tasarımları kullanıcılar tarafından "doğal" olarak algılanmış ve uygulandığı alanlarda da Şehirler Arası Otobüs Terminali-Asar Deresi-Çoban Dalçık sıralaması ile en çok doğal gözüken, uygulandığı alanda doğal bir ortam algısı oluşturan değerlendirilmesi sonucuna ulaşılmıştır.

Plastik malzemelerle oluşturulan dikey bahçe tasarımları kullanıcılar tarafından "yapay" olarak algılanmış ve uygulandığı alanlarda da Şehirler Arası Otobüs Terminali- Çoban Dalçık-Asar Deresi sıralaması ile en çok yapay gözüken, uygulandığı alanda yapay bir ortam algısı oluşturan değerlendirilmesi sonucuna ulaşılmıştır.

Konuşan duvar şeklinde oluşturulan dikey bahçe tasarımları kullanıcılar tarafından "yapay" olarak algılanmış ve uygulandığı alanlarda da Şehirler Arası Otobüs Terminali- Çoban Dalçık-Asar Deresi sıralaması ile en çok yapay gözüken, uygulandığı alanda yapay bir ortam algısı oluşturan değerlendirilmesi sonucuna ulaşılmıştır.

-Estetik-estetik değil sıfat çifti:

Bitkisel malzemelerle oluşturulan dikey bahçe tasarımları kullanıcılar tarafından "estetik" olarak algılanmış ve uygulandığı alanlarda da Şehirler Arası Otobüs Terminali- Çoban Dalçık-Asar Deresi sıralaması ile en çok estetik gözüken, uygulandığı alanda da estetik bir yap1 algısı oluşturan değerlendirilmesi sonucuna ulaşılmıştır. 
Plastik malzemelerle oluşturulan dikey bahçe tasarımları kullanıcılar tarafından "estetik değil" olarak algılanmış ve uygulandığı alanlarda da Şehirler Arası Otobüs Terminali-Asar Deresi-Çoban Dalçık sıralaması ile estetik görüntüden uzak gözüken bir yapı algısı oluşturan değerlendirilmesi sonucuna ulaşılmıştır.

Konuşan duvar şeklinde oluşturulan dikey bahçe tasarımları kullanıcılar tarafından "estetik değil" olarak algılanmış ve uygulandığı alanlarda da Şehirler Arası Otobüs Terminali-Asar Deresi-Çoban Dalçık sıralaması ile estetik görüntüden uzak gözüken bir yapı algısı oluşturan değerlendirilmesi sonucuna ulaşılmıştır.

-Uyumlu-uyumsuz sıfat çifti:

Bitkisel malzemelerle oluşturulan dikey bahçe tasarımları kullanıcılar tarafından "uyumlu" olarak algılanmış ve uygulandığı alanlarda da Şehirler Arası Otobüs Terminali- Çoban Dalçık-Asar Deresi sıralaması ile en çok uyumlu gözüken, uygulandığı alanla da uyumlu bir ortam algısı oluşturan değerlendirilmesi sonucuna ulaşılmıştır.

Plastik malzemelerle oluşturulan dikey bahçe tasarımları kullanıcılar tarafından "uyumlu" olarak algılanmış ve uygulandığı alanlarda da Asar Deresi- Çoban Dalçık- Şehirler Arası Otobüs Terminali sıralaması ile en çok uyumlu gözüken, uygulandığı alanla da uyumlu bir ortam algısı oluşturan değerlendirilmesi sonucuna ulaşılmıştır.

Konuşan duvar şeklinde oluşturulan dikey bahçe tasarımları kullanıcılar tarafından "uyumsuz" olarak algılanmış ve uygulandığı alanlarda da Şehirler Arası Otobüs Terminali- Çoban Dalçık-Asar Deresi sıralaması ile uyumsuz gözüken bir yapı algısı oluşturan değerlendirilmesi sonucuna ulaşılmıştır.

-Karışık-anlaşılır sıfat çifti:

Bitkisel malzemelerle oluşturulan dikey bahçe tasarımları kullanıcılar tarafından "anlaşılır" olarak algılanmış ve uygulandığı alanlarda da Şehirler Arası Otobüs Terminali- Çoban Dalçık-Asar Deresi sıralaması ile en çok anlaşılır gözüken, uygulandığı alanla da anlaşılır bir ortam algısı oluşturan değerlendirilmesi sonucuna ulaşılmıştır.

Plastik malzemelerle oluşturulan dikey bahçe tasarımları kullanıcılar tarafından "anlaşılır" olarak algılanmış ve uygulandığı alanlarda da Asar Deresi- Çoban Dalçık- Şehirler Arası Otobüs Terminali sıralaması ile en çok anlaşılır gözüken, uygulandığı alanla da anlaşılır bir ortam algısı oluşturan değerlendirilmesi sonucuna ulaşılmıştır.

Konuşan duvar şeklinde oluşturulan dikey bahçe tasarımları kullanıcılar tarafından "anlaşılır" olarak algılanmış ve uygulandığı alanlarda da Asar Deresi- Çoban Dalçık- Şehirler Arası Otobüs Terminali sıralaması ile en çok anlaşılır gözüken, uygulandığı alanla da anlaşılır bir ortam algısı oluşturan değerlendirilmesi sonucuna ulaşılmıştır.

-Modern-sıradanlık hissi sıfat çifti:

Bitkisel malzemelerle oluşturulan dikey bahçe tasarımları kullanıcılar tarafından "modern" olarak algılanmış ve uygulandığı alanlarda da Şehirler Arası Otobüs Terminali- Çoban Dalçık-Asar Deresi sıralaması ile en çok modern bulunan, uygulandığı alanda da modern bir ortam algısı oluşturan değerlendirilmesi sonucuna ulaşılmıştır.

Plastik malzemelerle oluşturulan dikey bahçe tasarımları kullanıcılar tarafından "modern" olarak algılanmış ve uygulandığı alanlarda da Asar Deresi- Çoban Dalçık- Şehirler Arası Otobüs Terminali sıralaması ile en çok modern bulunan, uygulandığı alanda da modern bir ortam algısı oluşturan değerlendirilmesi sonucuna ulaşılmıştır.

Konuşan duvar şeklinde oluşturulan dikey bahçe tasarımları kullanıcılar tarafından "sıradan" olarak algılanmış ve uygulandığı alanlarda da Çoban Dalçık- Şehirler Arası Otobüs Terminali- Asar Deresi sıralaması ile en çok sıradan bulunan, uygulandığı alanda da sıradanlık hissi veren bir ortam algısı oluşturan değerlendirilmesi sonucuna ulaşılmıştır. 
Çalışmanın sonucunda elde edilen bulgularda sıfat çiftleri kullanıcıların algılarına göre tanımlanarak tasarlanacak bir dikey bahçenin hangi niteliklerle oluşturulması gerektiği ile ilgili belirli bir sonuca ulaşmamızı sağlamıştır. Katılımcıların tasarımları algılamada oluşturulan malzemelere ve uygulandıkları alanlara göre değişimler gösterdiği ama genel olarak dikey bahçelere olumlu baktıkları görülmüss, kullanılan malzemeye göre de tercihleri saptanmıştır.

\section{IV.SONUC}

Anket ortalamalarından oluşturulan tablo ve gruplar arası anlamlılık incelendiğinde katılımcıların en yüksek beğeniyi bitkisel malzemeyle oluşturulan dikey bahçeye gösterdiği, ardından plastik objelerden oluşturulan dikey bahçelerin geldiği ve en düşük beğeninin ise konuşan duvarlara olduğu görülmüştür. Böylelikle çalışma kapsamında elde edilen verilere göre katılımcıların doğallık esasıyla kötü görüntülerin giderilmesi için bitkilerden meydana gelen dikey bahçeleri tercih ettikleri sonucuna ulaşılmıştır.

Dikey bahçelerin tercih edilmesinin giderek artmasıyla, kentlerde alternatif yeşilin yanı sıra akılda kalıcılık adına da insanların bu tür uygulamaları çevrelerinde görmek istemeleri ve Düzce gibi gelişmekte olan kentlerde farklı bir kullanım olarak uygulanabilec ĕgi fikrinin doğru bulunması da dikey bahçeler için olumlu yönde bir etkidir.

Sürdürülebilir peyzaj mimarlığın bir parçası haline gelen dikey bahçe uygulamaları, bu çalışma doğrultusunda elde edilen sonuçlara göre hem uygulandığı alanda hem de kişiler üzerinde estetik ve doğallık olguları katarak; kişilerde olumlu psikolojik etkilere, uygulandığı alanda tasarım değerlerini yükseltip mekana değer kazandırmakta ve kentliler için her gün önünden geçtiği alanların durup seyretmeye, dinlenmeye değer mekanlara dönüşebileceği etkisi bırakmıştır.

TEȘEKKÜR: Bu makale "Düzce Kentinde Dikey Bahçe Uygulanabilirliğinin Araştırılması" isimli yüksek lisans tez çalışmasından üretilmiştir.

\section{KAYNAKLAR}

[1] Şengül Durucu. (2019, 15 Ocak). Tembellikten Doğan Bir Ekosanat Anlayışı : 14 Madde Dikey Bahçeler [Çevrimiçi]. Erişim: https:listelist.com/dikey-bahce/.

[2]Anonim (2019, 05 Ocak). Dikey Bahçeler [Çevrimiçi]. Erişim: https:www.peyzaj.org.tr/resimler/ekler/6e2d3669e60bdfe.

[3] International Refereed Journal Of Design And Architecture, The evolution of verticalgardens, Say1: 13 Y11: 2018.

[4] A. L. Bjerre, “Green wall”, Doktora Tezi, VIA University College, Horsens, Danimarka, 2011.

[5] Anonim (2019, 25 Eylül ). Grafiti [Çevrimiçi].Erişim:https://tr.wikipedia.org/wiki/Grafiti.

[6] B. Bal, "Grafiti ve Sokak Sanatında Eser ve Akımların Tarihsel Süreçte Değerlendirilmesi ve Analizi", Yüksek Lisans Tezi, Güzel Sanatlar Bölümü, Haliç Üniversitesi, İstanbul, Türkiye, 2014.

[7] F. K. Satıc1, "Sanatta bir özgürleşme ve kapatılma biçimi olarak grafiti", Doktora Tezi, Sahne ve Görüntü Sanatları Bölümü, Marmara Üniversitesi, İstanbul, Türkiye, 2009. 
[8] Oğuz Kuş, (2019, 25 Eylül ). "Graffiti Nedir? Sokak Sanatına Üzerine Notlar" [Çevrimiçi]. Erişim: https://www.dadatart.com/author/oguz.

[9] Anonim (2019, 15 Ocak ). Terminal Açılış Haberi [Çevrimiçi]. Erişim: https://duzce.bel.tr/3734terminal-acilisa-gun-sayiyor.

[10] C. Acar, Demirtaş, E. ve H. Acar, "Anlamsal farklılaşım tekniği bitki kompozisyonu örneklerinde değerlendirilmesi”, S.D.Ü. Orman Fakültesi Dergisi, c. A, ss. 15-28, 2003.

[11] Summit, J. and Sommer, R., "Further studies of preferred three shapes environment behavior" Art Department at the University of California, vol. 31, no.4, pp. 550-576, 1999.

[12] DE La Fuente G.,Ataurı J.A. and De lucio J.V., "Relationship Between Landscape Visual Attributesand Spatial PatternIndices: A Test study in Mediterranean-ClimateLandscapes", Landscapeand Urban Planning, vol. 77, pp. 393-407, 2006.

[13] R. S. Ulrich, "Natural Versus Urban Scenes: Some Psychophysiological Effects", Environment and Behavior, vol. 13, no. 5, pp. 523-556, 1991.

[14] A. Kalın, "Çevre Tercih ve Değerlendirmede Görsel Kalite Belirlenmesi ve Geliştirilmesi: Trabzon Sahil Bandı Örneği ”, Doktora Tezi, Peyzaj Mimarlığı Anabilim Dalı, Karadeniz Teknik Üniversitesi, Trabzon, Türkiye, 2004. 